\title{
COMPREHENSIVE MONITORING REPORT FOR UNDERGROUND STORAGE TANKS \\ 1219-U, 1222-U, 2082-U, AND 2068-U AT THE \\ RUST GARAGE FACILITY \\ BUILDINGS 9720-15 \\ AND 9754-1
}

\author{
OAK RIDGE Y-12 PLANT \\ OAK RIDGE, TENNESSEE \\ FACILITY ID \#0-010117
}

June 1994

Environmental Management Department

Health, Safety, Environment, and Accountability Organization

\section{Prepared by}

Science Applications International Corporation

Under Subcontract 22B-99069C

for the

Oak Ridge Y-12 Plant

Oak Ridge, Tennessee 37831

\section{Managed by}

Martin Marietta Energy Systems, Inc.

for the

U.S. Department of Energy

Under Contract No. DE-AC05-840R21400

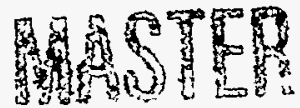




\section{DISCLAIMER}

This report was prepared as an account of work sponsored by an agency of the United States Government. Neither the United States Government nor any agency thereof, nor any of their employees, make any warranty, express or implied, or assumes any legal liability or responsibility for the accuracy, completeness, or usefulness of any information, apparatus, product, or process disclosed, or represents that its use would not infringe privately owned rights. Reference herein to any specific commercial product, process, or service by trade name, trademark, manufacturer, or otherwise does not necessarily constitute or imply its endorsement, recommendation, or favoring by the United States Government or any agency thereof. The views and opinions of authors expressed herein do not necessarily state or reflect those of the United States Government or any agency thereof. 


\section{DISCLAIMER}

Portions of this document may be illegible in electronic image products. Images are produced from the best available original document. 


\section{TABLE OF CONTENTS}

LIST OF FIGURES

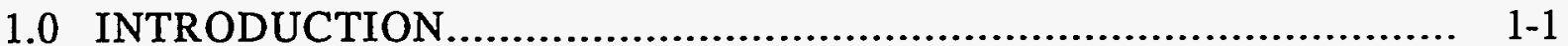

1.1 Purpose and Scope .......................................................... 1-1

1.2 Site Description............................................................. $1-1$

2.0 GROUNDWATER MONITORING ....................................... $2-1$

2.1 Groundwater Measurement, Sample Collection and Analysis................. 2-1

2.1.1 Well Locations................................................. 2-1

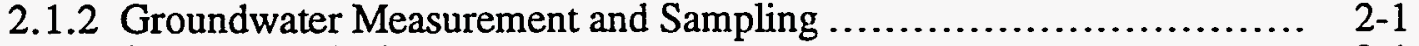

2.1.3 Sample Analysis................................................... 2-1

2.2 Photentiometric Data....................................................... 2-1

2.3 Analytical Data................................................................. 2-1

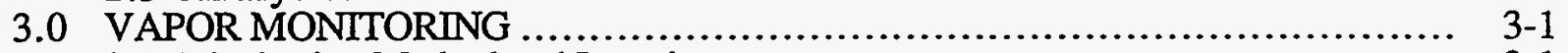

3.1 Monitoring Method and Locations ............................................... $3-1$

3.2 Vapor Monitoring Results........................................... $3-1$

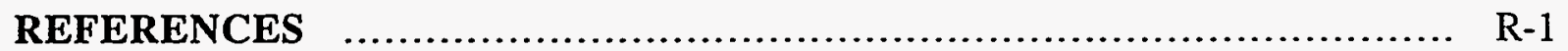

APPENDICES

Appendix A $\quad$ Laboratory Analytical Results for Comprehensive Monitoring........... A-1 


\section{LIST OF FIGURES}

Figure Title Page

1-1 Location of the Rust Garage Facility at the Y-12 Plant...................... 1-2

1-2 Rust Garage Facility Site Map................................................ 1-3

2-1 Rust Garage Facility Site Monitoring Well and Soil Borehole Location Map .. $\quad 2-2$

2-2 Rust Garage Facility Site Groundwater Potentiometric Contour Map,

2-3 Rust Garage Facility Site Groundwater Potentiometric Contour Map,

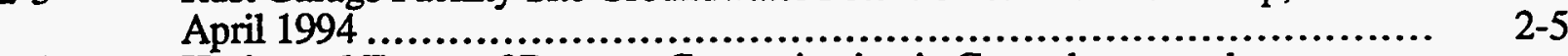

2-4 Horizontal Extent of Benzene Contamination in Groundwater at the

2-5 Horizontal Extent of TPH Contamination in Groundwater at the Rust Garage

3-1 Rust Garage Facility Vapor Monitoring Sampling Point Location Map......... $\quad 3-2$

Table Title $\quad$ Page

2-1 Water Level Measurements at the Rust Garage Facility for the Periods of November 1993 and April 1994 .............................................. 2-3

2-2 Analytical Results for Groundwater Samples Collected During Comprehensive Monitoring and 1993 Y-12 UEFPC Groundwater

3-1 Vapor Monitoring Results for the Rust Garage Facility. 


\section{LIST OF ACRONYMS}

BGL below ground level

BTEX benzene, toluene, ethylbenzene, and xylene

BTOC below top of casing

CAP Corrective Action Plan

MSL mean sea level

TDEC

Tennessee Department of Conservation

TPH-DRO total petroleum hydrocarbons - gasoline range organics

TPH-GRO total petroleum hydrocarbons - gasoline range organics

TWA total weight average

UST underground storage tank 


\section{SIGNATURE PAGE}

I certify under penalty of law, including but not limited to penalties for perjury, that the information contained in this report and on any attachments, is true, accurate and complete to the best of my knowledge, information, and belief. I am aware that there are significant penalties for submitting false information, including the possibility of fine and imprisonment for intentional violations.

See Attached Certification

Owner/Operator (Print)

$\overline{\text { Signature }} \overline{\text { Date }}$

W. David Kecfer

Lillim Q Regh/TN3328 5/6/94

P.E. or P.G. (Print)

Signature TN Lic./Reg. \# Date

If a P.E. signs this report, please indicate the area of expertise.

(Print or Type)

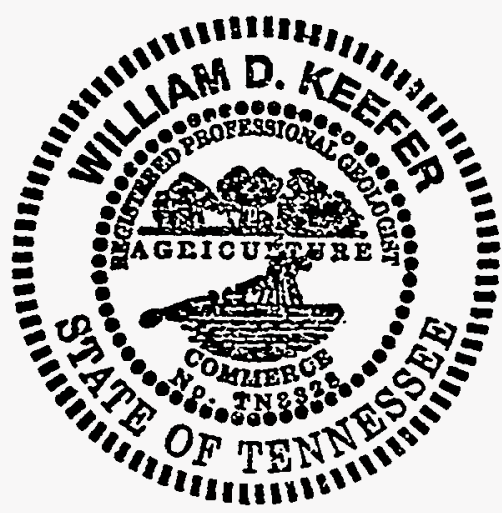

(P.E./P.G. Stamp/Seal)

County of Axdesson State of Senmessece.
Subscribed and Sworn to before me this
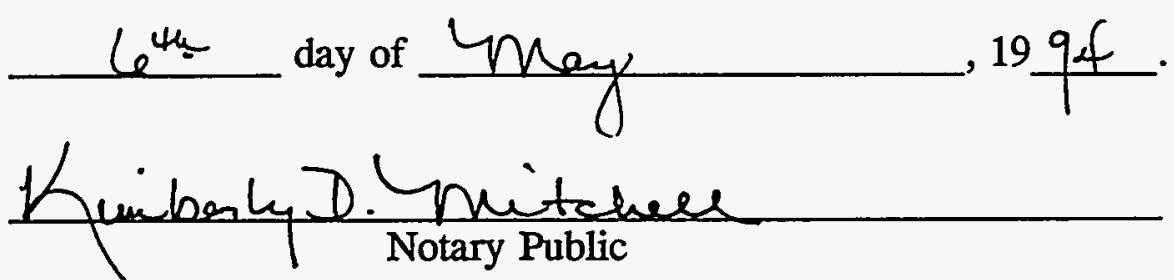

My Commission expires:

MY MMMMISSINMN FYPIRFS SFPT. 23. 1997

(Notary Seal) 


\section{CERTIFICATION STATEMENT FOR THE COMPREHENSIVE MONITORING REPORT FOR THE UNDERGROUND STORAGE TANKS 1219-U, 1222-U, 2082-U, AND 2068-U AT THE \\ RUST GARAGE FACILITY \\ BUILDINGS 9720-15 AND 9754-1}

I certify that this document and all enclosures were prepared under my direction or supervision in accordance with a system designed to ensure that qualified personnel properly gather and evaluate the information submitted. Based on my inquiry of the person or persons directly responsible for gathering the information, the information submitted is, to the best of my knowledge and belief, true, accurate, and complete.

U.S. Department of Energy

Owner and operator

By:
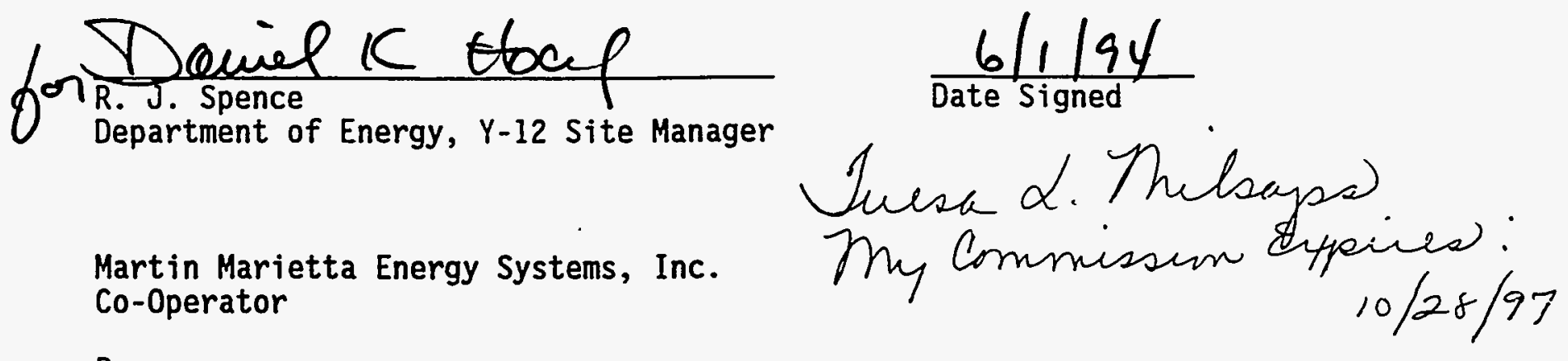

By:

Martin Marietta Energy Systems, Inc. Co-Operator

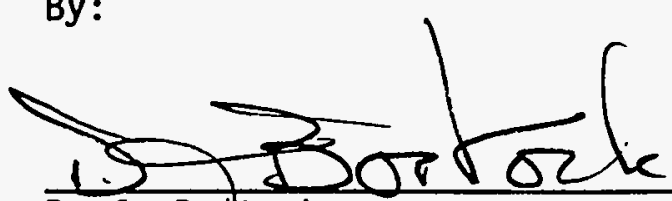

D. J. Bostock

Mart in Marietta Energy Systems, Inc.

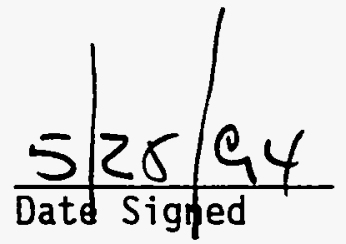

Vice President and Y-12 Plant Manager

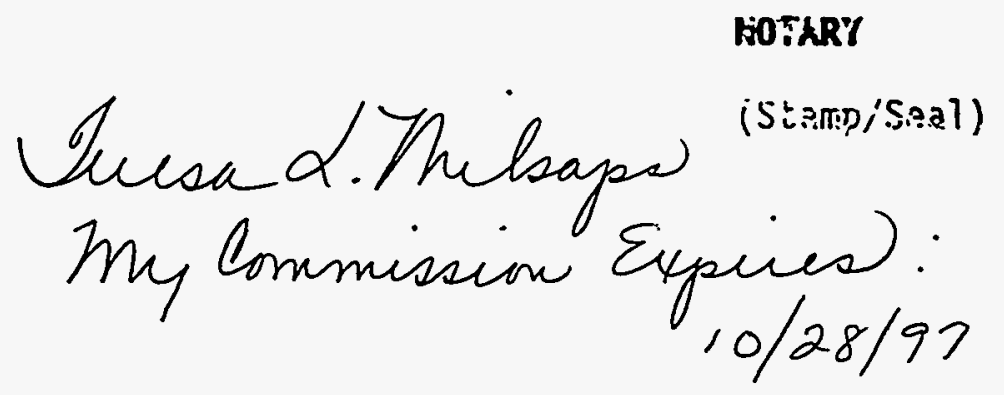

Note: Both signatures have been notarized per requirements. 


\subsection{INTRODUCTION}

\subsection{PURPOSE AND SCOPE}

The purpose of this document is to provide hydrogeologic, geochemical, and vapor monitoring data required for comprehensive monitoring of underground storage tanks (UST) 1219-U, 1222-U, 2082-U, and 2068-U at the Rust Garage Facility. Comprehensive monitoring has been conducted at the site as part of a Monitoring Only program approved by Tennessee Department of Environment and Conservation (TDEC) based on review and approval of Site Ranking (Site Ranking Form dated February 28, 1994). Site Status Monitoring will be conducted semiannually. Comprehensive monitoring and preparation of this report have been conducted in accordance with the requirements of the TDEC Rule 1200-1-15, the TDEC UST Reference Handbook, Second Edition (TDEC 1994), and direction from TDEC (letter from Jim Harless to Robert Spence, dated March 7, 1994).

This document is organized into three sections. Section 1 presents introductory information relative to the site including regulatory initiative and a site description. Section 2 includes the results of sampling of monitoring wells GW-508, GW-631, GW-632, and GW-634. Section 3 presents data from vapor monitoring conducted in subsurface utilities present at the site.

\subsection{SITE DESCRIPTION}

The Rust Garage Facility is located at the western end of the Oak Ridge Y-12 Plant in Oak Ridge, Tennessee (Figure 1-1). The facility site is generally defined by the area surrounding the current locations of Buildings 9720-15 and 9831, and the former location of Building 9754-1 (Figure 1-2). This facility was formerly the location of four underground petroleum product storage tanks and was a fueling point for U.S. Department of Energy fleet vehicles.

The topography of the Rust Garage Facility generally decreases in elevation from north to south across the facility and is defined by two downward stepping terraces. The two terraces are separated by a steep embankment and a similar embankment is located along the northern side of the facility. Given the nature of the surface topography at the Rust Garage Facility, any petroleum product contamination resulting from past operations at the facility would be expected to migrate south away from the source area. 


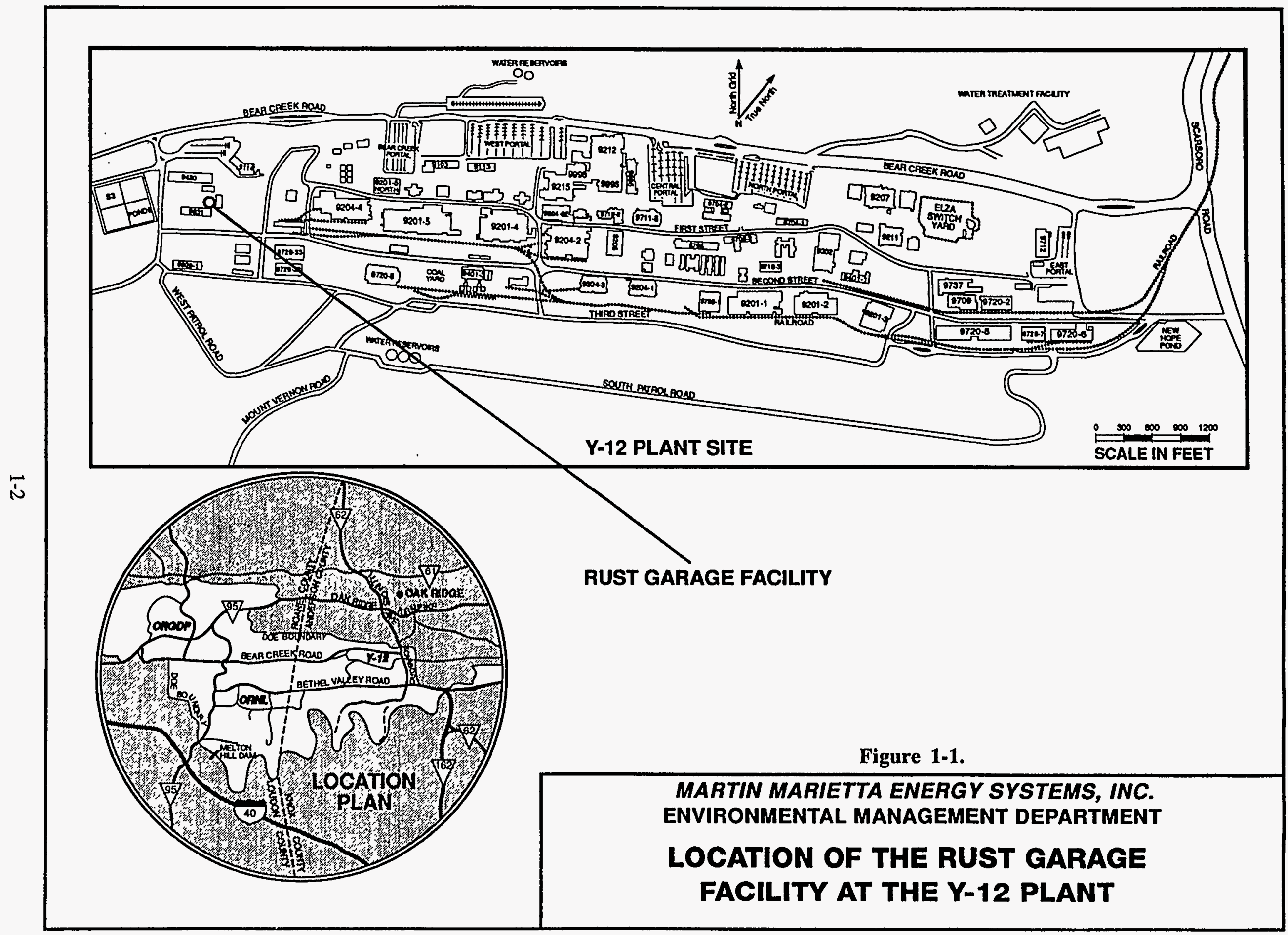




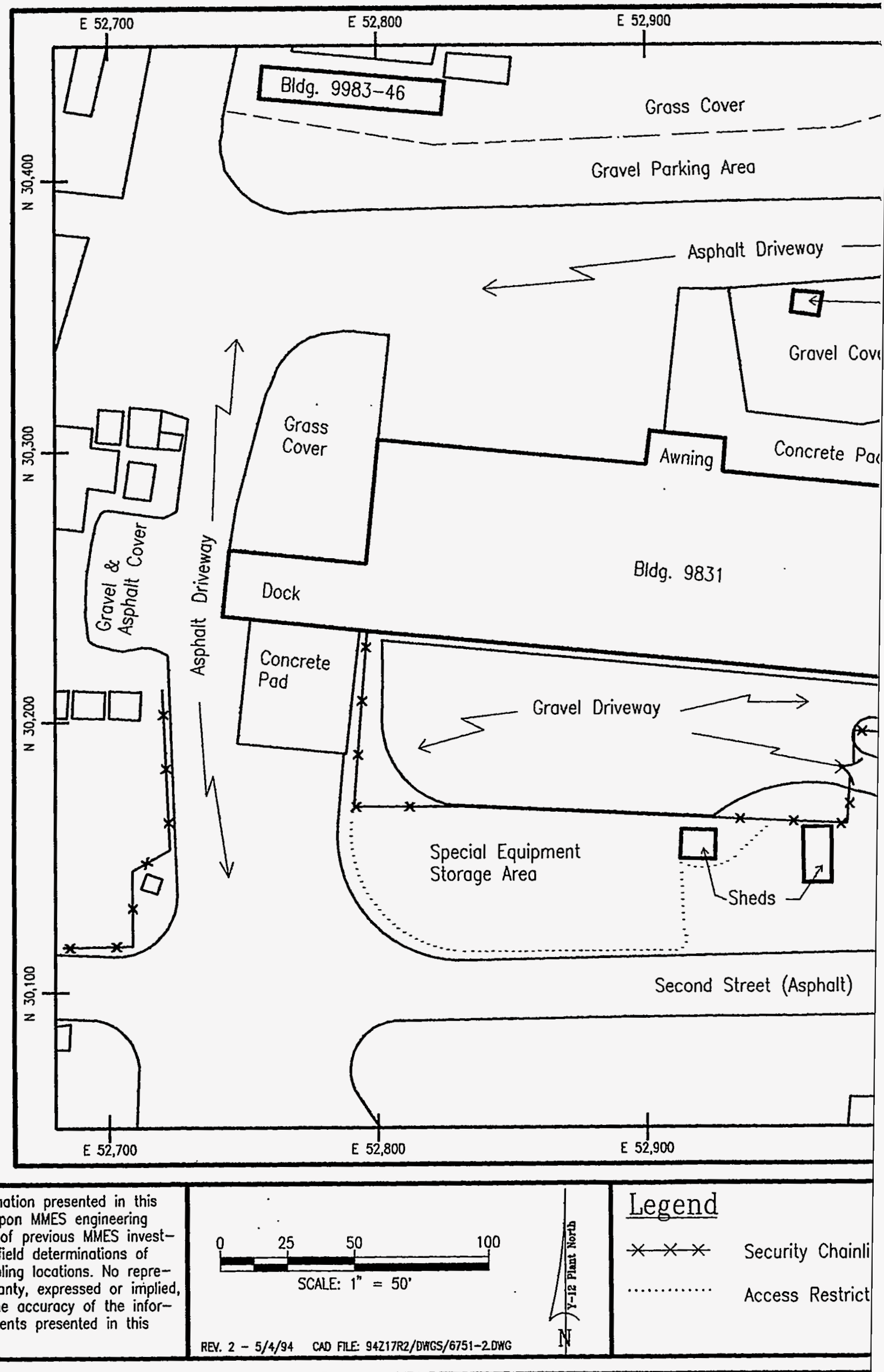

All locotion informotion presented in this figure is bosed upon MMES engineering drowings, results of previous MMES investigations, and/or field determinations of feoture and sampling locations. No representation or worronty, expressed or implied is made as to the accuracy of the informotion or statements presented in this figure. 


\subsection{GROUNDWATER MONITORING}

\subsection{Groundwater Measurement, Sample Collection and Analysis}

\subsubsection{Well Locations}

As directed by TDEC, four monitoring wells have been sampled as part of the Site Status Monitoring program for the site. These wells include GW-508, GW-631, GW-632, and GW-634. The location of these wells is presented in Figure 2-1. Well installation reports and construction details for these wells are presented in the Corrective Action Plan (CAP) for the Site (Corrective Action Plan for Underground Storage Tanks 1219-U, 1222-U, 2082-U and 2068-U at the Rust Garage Facility, Buildings 9720-15 and 9754-1, Appendix E, Martin Marietta Energy Systems, Inc., Y/SUB/92-99928C/1) (Energy Systems 1992).

\subsubsection{Groundwater Measurement and Sampling}

The specified groundwater monitoring wells at the Rust Garage Facility were measured for water level and sampled for the applicable petroleum constituents on April 5, 1994. Well GW-508 was purged of approximately 3 volumes prior to sampling. Wells GW-631, GW-632, and GW-634 were purged to dryness in an attempt to purge three volumes. Field measurement of $\mathrm{pH}$, conductivity, temperature, and dissolved oxygen was conducted during purging to ensure representativeness for sampling. The wells were allowed to recover and samples were collected for analysis in pre-prepared bottles. No measurable free product was encountered during water level measurement or sampling in any of the wells. However, a slight oily sheen was observed in the purge water at GW-508 and GW-632, and a fuel odor was observed when wells were opened and during sampling at GW-508, GW-632, and GW-634.

\subsubsection{Sample Analysis}

Samples were analyzed for total petroleum hydrocarbons (TPH) for gasoline range organics (TPH-GRO) and diesel range organics (TPH-DRO) and for benzene, toluene, ethylbenzene, and xylene (BTEX).

\subsection{POTENTIOMETRIC DATA}

Potentiometric data for monitoring wells GW-508, GW-631, GW-632, and GW-634 from the comprehensive monitoring sample event and from the last round of quarterly monitoring conducted as part of the 1993 Y-12 Plant, Upper East Fork Poplar Creek Hydrologic Regime Groundwater Quality Assessment (Calendar Year 1993 Groundwater Quality Report for the Upper East Fork Poplar Creek Hydrologic Regime, Y-12 Plant, Oak Ridge, Tennessee: 1993 Groundwater Quality Data and Calculated Rate of Contaminant Migration, Martin Marietta Energy Systems, Inc. Y/SUB/94-EAQ10C/2/P1) (Energy Systems 1994) are presented in Table 2-1. Figures 2-2 and 2-3 present potentiometric maps from these two periods of sampling. These figures illustrate that groundwater movement is generally from north to south across the site.

\subsection{ANALYTICAL DATA}

Analytical data for groundwater sampled at the site during comprehensive monitoring and analytical data for the last four rounds of groundwater sampling conducted in 1993 for Y-12 Plant, UST monitoring wells is summarized in Table 2-2. Sample values in this table for total TPH represent summations of TPH-GRO and TPH-DRO values. Where a TPH-GRO or TPH-DRO 


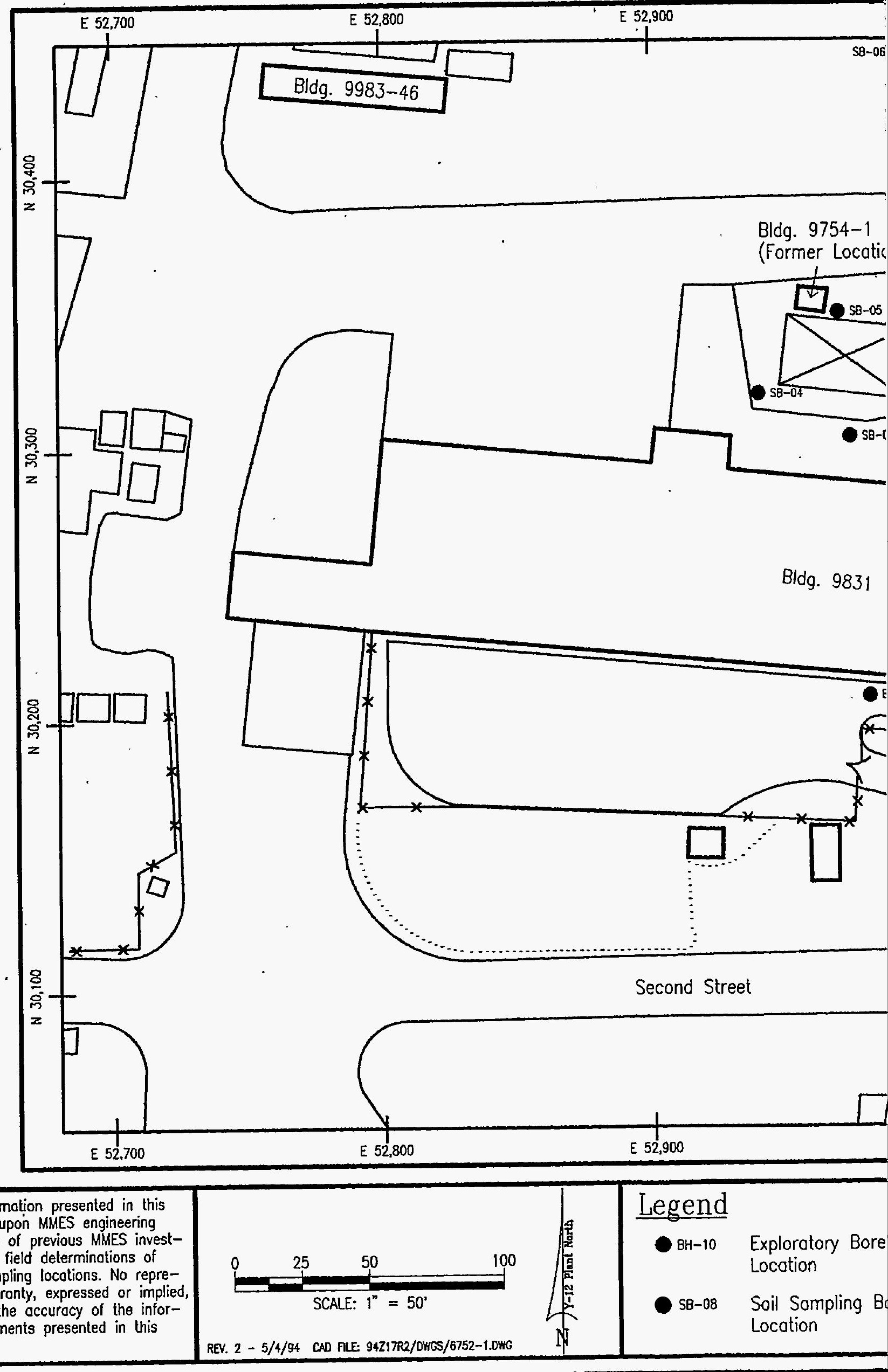


Table 2-1. Water Level Measurements at the Rust Garage Facility for the Periods of November 1993 and April 1994

\begin{tabular}{llcccc}
\hline Monitoring Well & Date Measured & $\begin{array}{c}\text { Total Well Depth } \\
(\mathbf{B G L})^{1}\end{array}$ & $\begin{array}{c}\text { Top of Casing } \\
(\mathbf{M S L})^{2}\end{array}$ & $\begin{array}{c}\text { Top of Casing to } \\
\text { Water Level } \\
\text { (BTOC) }^{\mathbf{3}}\end{array}$ & $\begin{array}{c}\text { Potentiometric } \\
\text { Surface } \\
(\text { MSL) }\end{array}$ \\
\hline GW-508 & $04 / 05 / 94$ & $15.0 \mathrm{ft}$ & $1012.5 \mathrm{ft}$ & $14.93 \mathrm{ft}$ & $997.57 \mathrm{ft}$ \\
& $11 / 19 / 93^{4}$ & $15.0 \mathrm{ft}$ & $1012.5 \mathrm{ft}$ & $11.35 \mathrm{ft}$ & $1001.15 \mathrm{ft}$ \\
GW-631 & $04 / 05 / 94$ & $16.0 \mathrm{ft}$ & $1003.99 \mathrm{ft}$ & $7.01 \mathrm{ft}$ & $996.98 \mathrm{ft}$ \\
& $11 / 17 / 93^{4}$ & $16.0 \mathrm{ft}$ & $1003.99 \mathrm{ft}$ & $6.85 \mathrm{ft}$ & $997.14 \mathrm{ft}$ \\
GW-632 & $04 / 05 / 94$ & $15.0 \mathrm{ft}$ & $1005.73 \mathrm{ft}$ & $7.40 \mathrm{ft}$ & $998.33 \mathrm{ft}$ \\
& $11 / 18 / 93^{4}$ & $15.0 \mathrm{ft}$ & $1005.73 \mathrm{ft}$ & $8.10 \mathrm{ft}$ & $997.63 . \mathrm{ft}$ \\
GW-634 & $04 / 05 / 94$ & $15.0 \mathrm{ft}$ & $1007.15 \mathrm{ft}$ & $7.97 \mathrm{ft}$ & $999.18 \mathrm{ft}$ \\
& $11 / 18 / 93^{4}$ & $15.0 \mathrm{ft}$ & $1007.15 \mathrm{ft}$ & $8.81 \mathrm{ft}$ & $998.34 . \mathrm{ft}$ \\
\hline
\end{tabular}

1BGL - Below Ground Level

${ }^{2}$ MSL - Mean Sea Level

${ }^{3}$ BTOC - Below Top of Casing

${ }^{4}$ Data Source: Calendar Year 1993 Groundwater Quality Report for the Upper East Fork Hydrogeologic Regime, Y-12 Plant, Oak Ridge, Tennessee, Y/SUB/94-EAQ10C/2/P1 (Energy Systems 1994) 


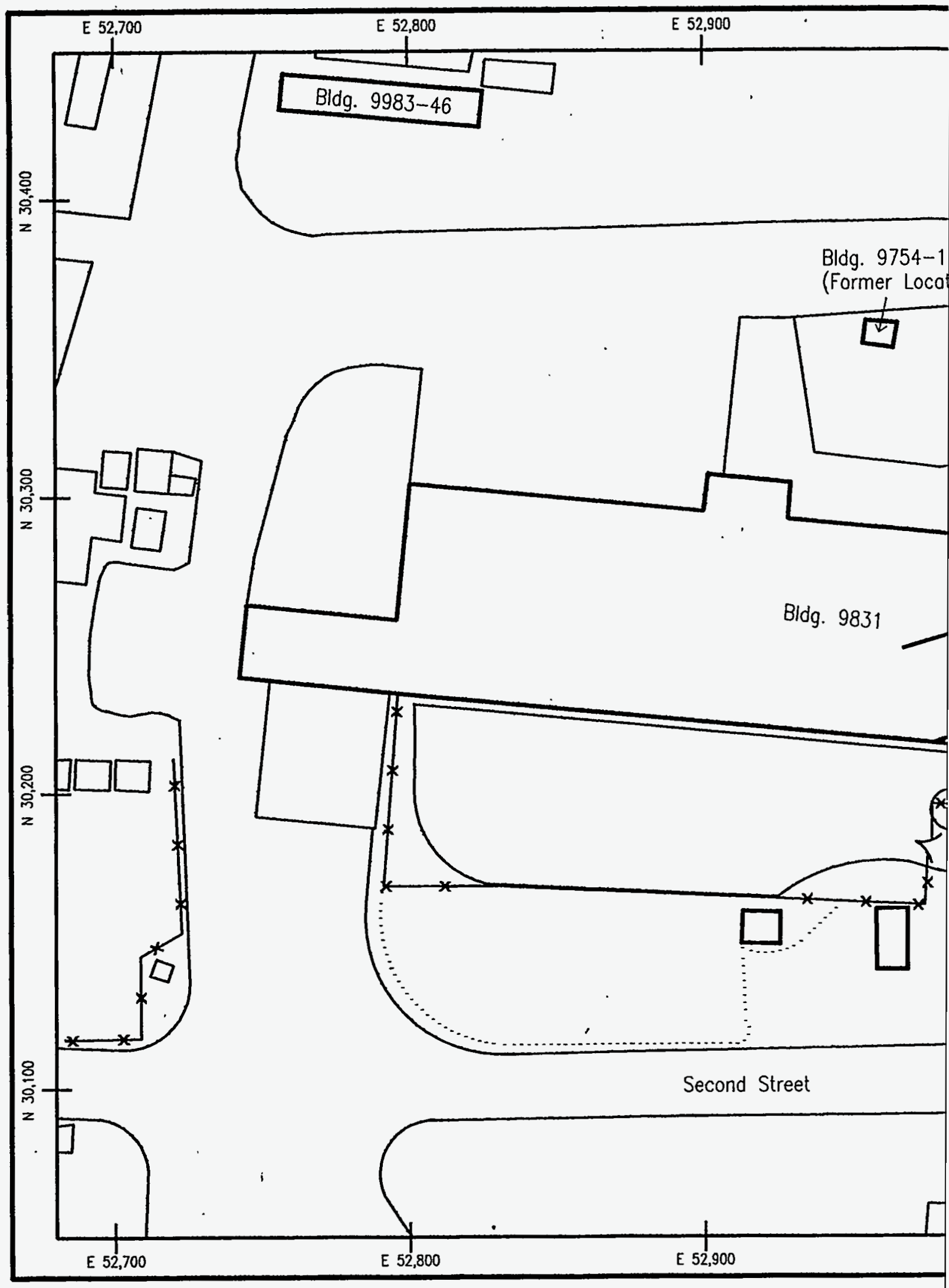

All locotion information presented in this figure is bosed upon MMES engineering drowings, results of previous MMES investigations, ond/or field determinations of feature and sampling locations. No representation or warranty, expressed or implied is mode as to the accuracy of the information or statements presented in this figure.

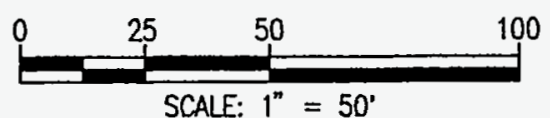

SCALF: $1^{\prime \prime}=50^{\prime}$

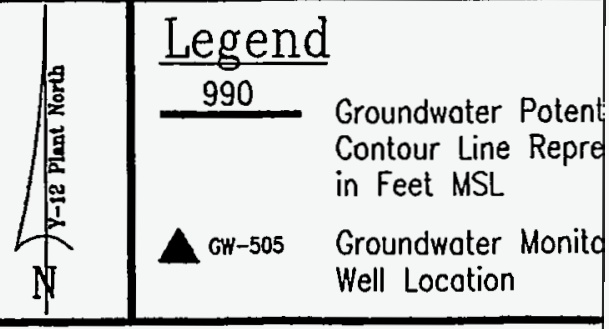




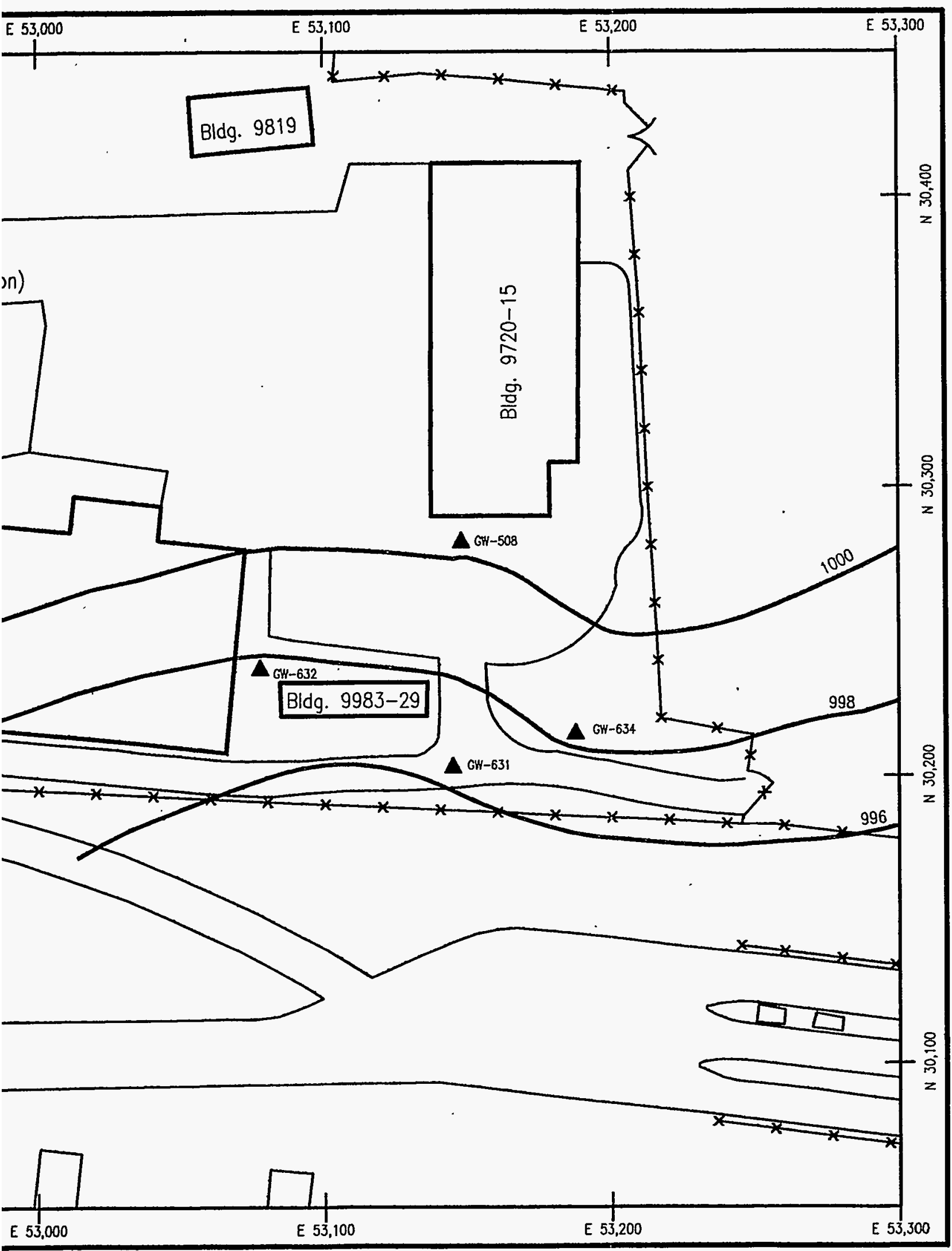

Summary of Meosured

Groundwater Elevations (MSL)

GW-508 $1001.15 \mathrm{FT}$.

GW-631 997.14 FT.

GW-632 $997.63 \mathrm{FT}$.

GW-634. 998.34 FT.
Martin Marietto Energy Systems, Inc. Environmental Monagement Deportment

FIGURE 2-2

Rust Garage Facility Site Groundwater Potentiometric Contour Map, November 1993 


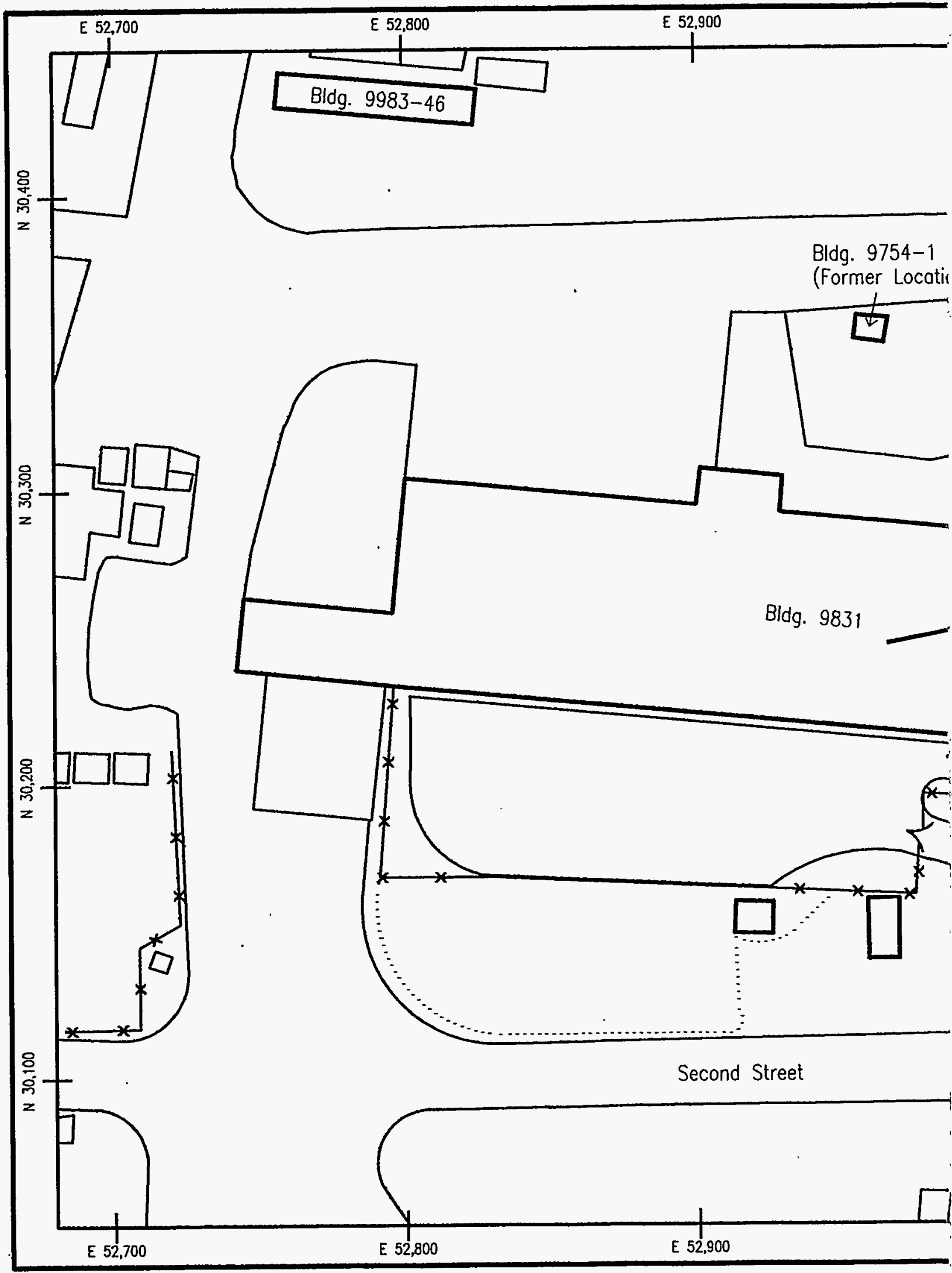

All location information presented in this figure is based upon MMES engineering drawings, results of previous MMES investigations, and/or field determinotions of feature and sompling locations. No representation or warranty, expressed or implied, is made os to the occuracy of the information or statements presented in this figure.

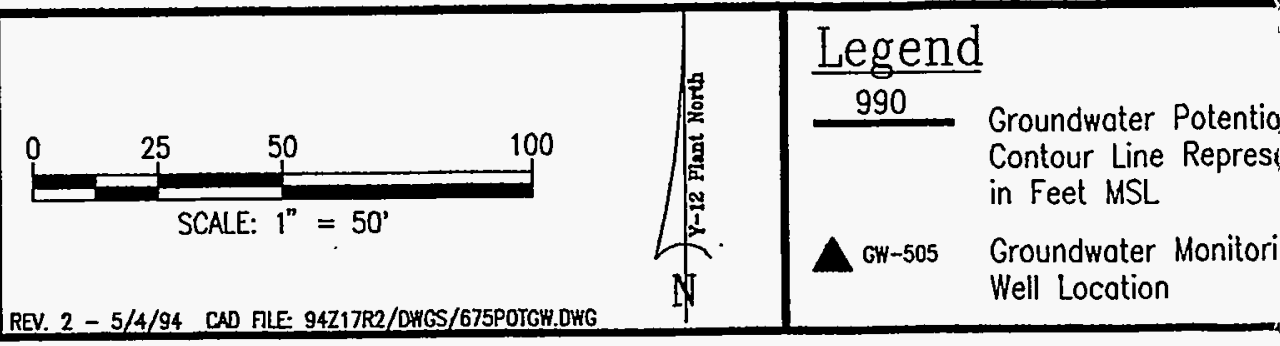




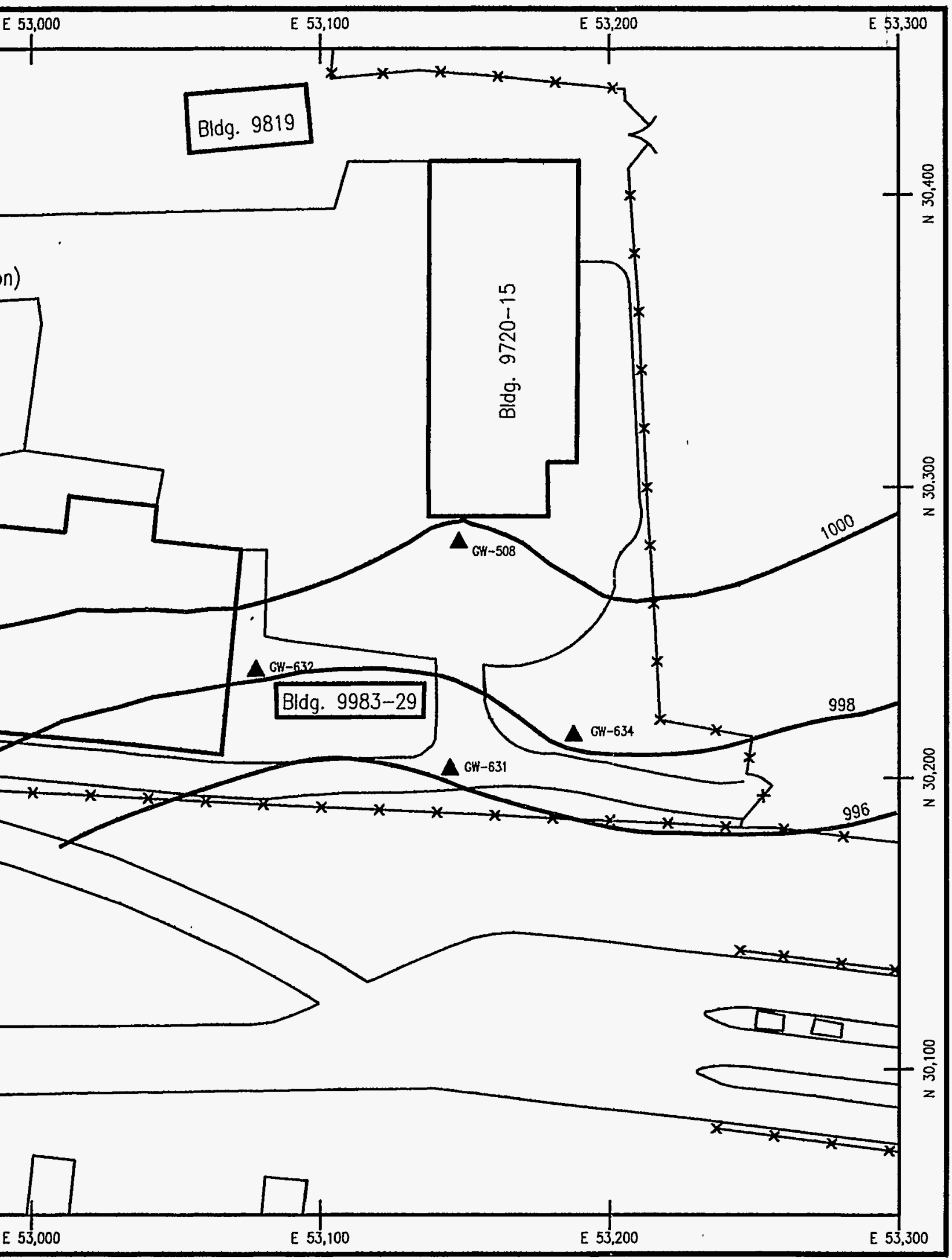

Summary of Measured

Groundwoter Elevations (MSL)

GW-508 $997.57 \mathrm{FT}$.

GW-631 $996.98 \mathrm{FT}$.

GW-632 $998.33 \mathrm{FT}$.

GW-634 999.34 FT.
Martin Marietto Energy Systems, Inc. Environmental Management Department

FIGURE 2-3

Rust Garage Facility Site Groundwater Potentiometric Contour Map, April 1994 
Table 2-2. Analytical Results for Groundwater Samples Collected During Comprehensive Monitoring and 1993 UST Monitoring Well Sampling

\begin{tabular}{|c|c|c|c|c|c|c|c|}
\hline Well No. & $\begin{array}{c}\text { TPH-DRO } \\
(\mathrm{ppm})\end{array}$ & $\begin{array}{c}\text { TPH-GRO } \\
(\mathrm{ppm})\end{array}$ & $\begin{array}{c}\text { Total TPH } \\
(\mathrm{ppm})\end{array}$ & $\begin{array}{c}\text { Benzene } \\
(\text { ppm) }\end{array}$ & $\begin{array}{c}\text { Ethyl benzene } \\
(p p m)\end{array}$ & $\begin{array}{c}\text { Toluene } \\
\text { (ppm) }\end{array}$ & $\begin{array}{l}\text { Xylene } \\
\text { (ppm) }\end{array}$ \\
\hline \multicolumn{8}{|c|}{$G W .508$} \\
\hline $\begin{array}{l}\text { Comprehensive } \\
\text { Monitoring }\end{array}$ & 60.000 & 69.000 & 129.000 & 5.600 & 2.200 & 26.000 & 15.000 \\
\hline 1993 Qtr 4 & 21.49 & - & & 0.1529 & 一 & $0.002 *$ & 1.271 \\
\hline 1993 Qtr 3 & 88.08 & - & & 6.346 & 一 & 8.064 & 12.919 \\
\hline 1993 Qtr 2 & 1422.9 & - & & 9.036 & - & 30.554 & 16.080 \\
\hline 1993 Qtr 1 & 24.06 & - & & 9.200 & - & 28.000 & 11.1 \\
\hline \multicolumn{8}{|c|}{$G W-631$} \\
\hline $\begin{array}{l}\text { Comprehensive } \\
\text { Monitoring }\end{array}$ & $0.057 \mathrm{~J}$ & $0.0100 \mathrm{U}$ & $0.557 \mathrm{~J}$ & $0.010 \mathrm{U}$ & $0.010 \mathrm{U}$ & $0.010 \mathrm{U}$ & $0.010 \mathrm{U}$ \\
\hline 1993 Qtr 4 & 0.002 & - & & $<0.005$ & - & $<0.005$ & $<0.005$ \\
\hline 1993 Qtr 3 & 0 & - & & $<0.005$ & 一 & $<0.005$ & $<0.005$ \\
\hline 1993 Qtr 2 & $<0.1$ & - & & $<0.005$ & - & $<0.005$ & $<0.005$ \\
\hline 1993 Qtr 1 & 0.003 & - & & 0.0017 & - & $<0.005$ & $<0.005$ \\
\hline \multicolumn{8}{|c|}{$G W-632$} \\
\hline $\begin{array}{l}\text { Comprehensive } \\
\text { Monitoring }\end{array}$ & 14.000 & 27.000 & 41.000 & 9.200 & $2.000 \mathrm{U}$ & 2.600 & 3.200 \\
\hline 1993 Qtr 4 & 4.2 & - & . & 0.4529 & - & 0.2614 & 0.165 \\
\hline 1993 Qtr 3 & 2.61 & - & & 4.329 & - & 0.580 & 2.891 \\
\hline 1993 Qtr 2 & 3.3 & - & & 6.924 & - & 5.518 & 3.746 \\
\hline 1993 Qtr 1 & 2.098 & - & & 10.440 & - & 3.865 & 1.557 \\
\hline \multicolumn{8}{|c|}{$G W-634$} \\
\hline $\begin{array}{l}\text { Comprehensive } \\
\text { Monitoring }\end{array}$ & 11.000 & 8.600 & 19.600 & 0.260 & 0.500 & 0.340 & 1.900 \\
\hline 1993 Qtr 4 & 5.16 & - & & 0.0568 & - & 0.597 & 0.1096 \\
\hline 1993 Qtr 3 & 2.48 & - & & 0.309 & - & 0.3215 & 1.2656 \\
\hline 1993 Qtr 2 & 4.48 & - & & 0.018 & 一 & 0.570 & 1.604 \\
\hline 1993 Qtr 1 & 6.032 & - & & 0.425 & - & 0.251 & 2.083 \\
\hline
\end{tabular}

$\mathrm{U}$ - Compound not detected at the reported minimum attainable detection limit.

J - Estimated Value.

* Interference Peak 
result is qualified as a non-detect (U qualifier) and the detection limit is given, one-half the detection limit is used to calculate total TPH. Where estimated values are used to calculate total TPH, the J qualifier is assigned to the total value. Laboratory analytical sheets for these analyses are presented in Appendix A. The delineation of the horizontal extent of benzene contamination, based on comprehensive monitoring results, is presented in Figure 2-4. Figure 2-5 presents the extent of TPH contamination in groundwater. Also presented in these figures are the maximum analytical results for TPH and BTX in soil, determined during the Site Investigation, May 1990 (Energy Systems 1992).

Figure 2-4, Figure 2-5, and Table 2-2 illustrate contamination in monitoring wells GW-508, GW-632, and GW-634 above TDEC non-drinking water Closure Action Limits of $0.07 \mathrm{ppm}$ benzene and $1.0 \mathrm{ppm}$ TPH. Wells GW-632 and GW-634 have historically produced values in excess of these closure limits. Comprehensive monitoring results indicate an extension of TPH contamination to include GW-508. Comprehensive monitoring analytical results from GW-631 illustrate that contamination has not migrated downgradient to the location of this well. 


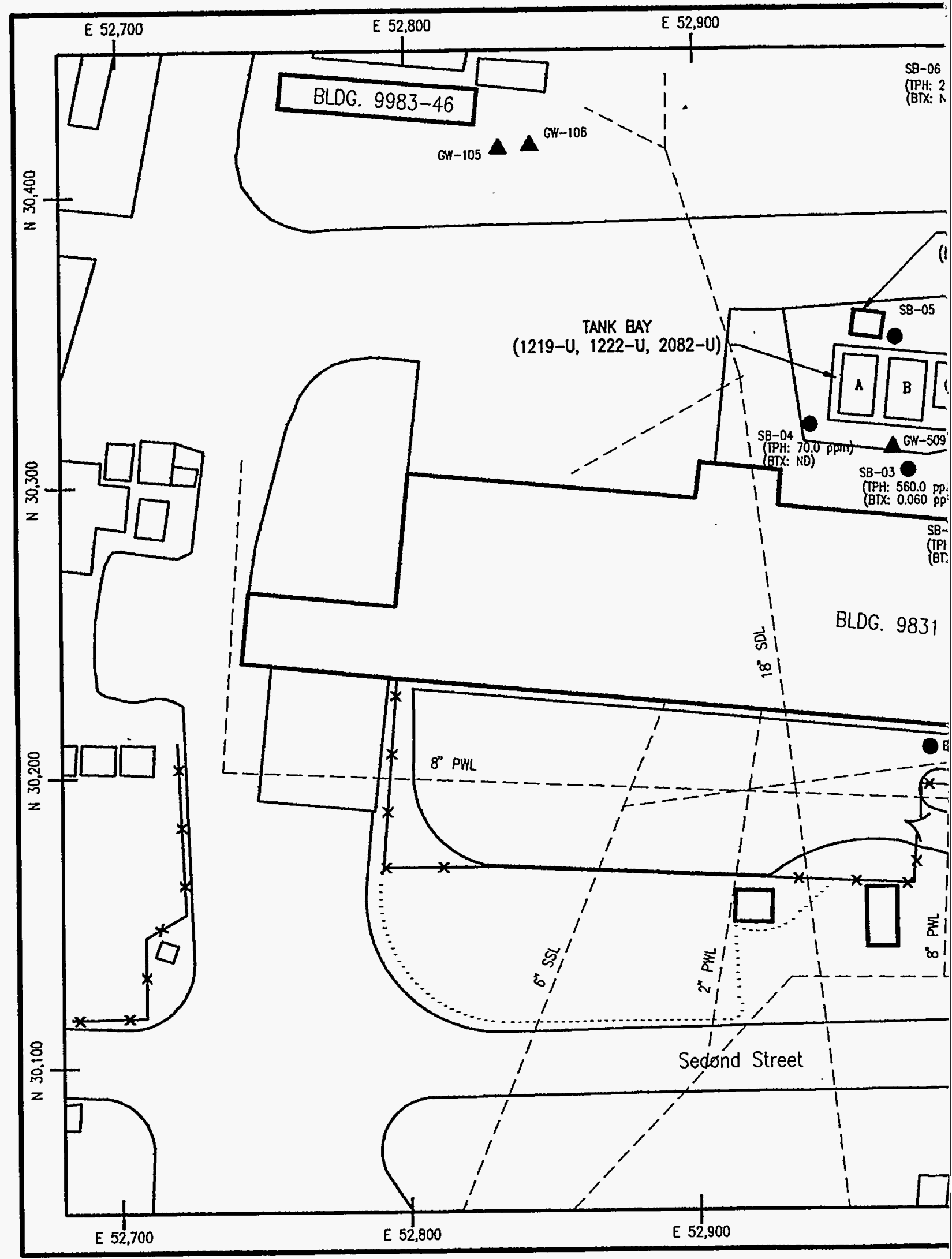

All location information presented in this figure is based upon MMES engineering drawings, results of previous MMES investigations, and/or field determinations of feature and sompling locations. No representation or warranty, expressed or implied is made os to the accuracy of the information or statements presented in this figure.
SCALE: $1^{\prime \prime}=50^{\prime}$

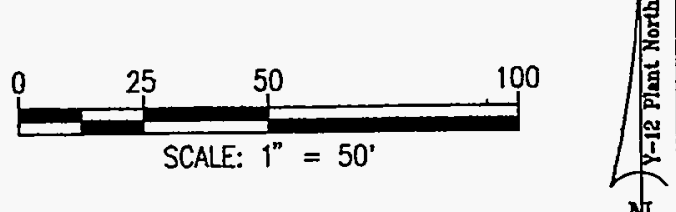

Legend
$X 7$ Groundwoter Contamination: $>0.07$ ppm Benzene

Groundwater Contamination: > 0.005 ppm Benzene 


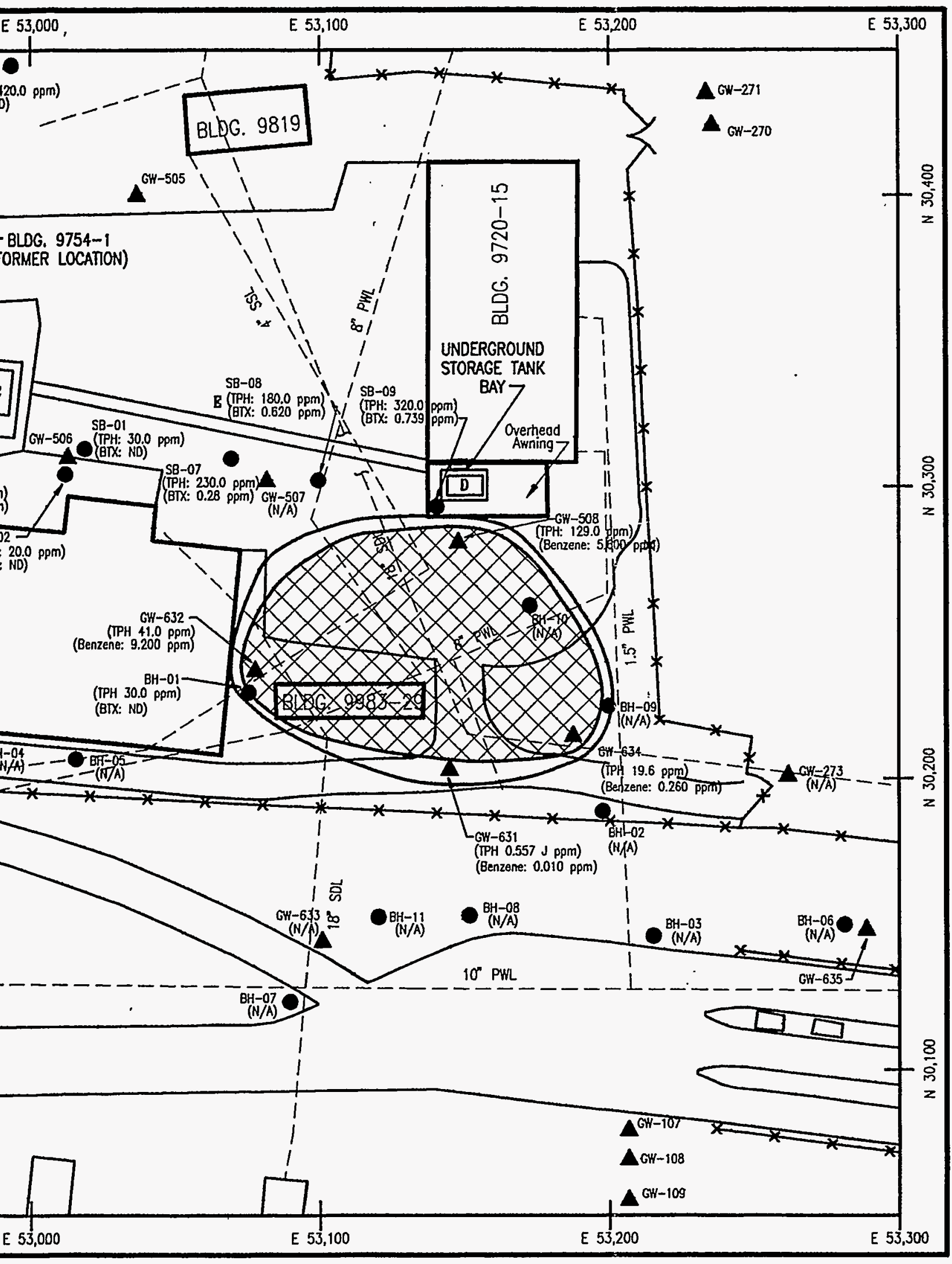

A-Tonk 1219 U, 12000 Gollon Diesel UST

B - Tank 1222-U, 12000 Gallon UST

C - Tank 2082-U, 8000 Gollon Gosoline UST

D - Tonk 2068-U, 1000 Gallon Gasoline UST

$\mathrm{E}$ - Underground Gosoline Transfer Pipeline
A GW-508 Monitoring Hell Location

- SB-01 Soil Boring Location \& Maximum Soil Anolytical Result for TPH \& BTX

- SDL - Underground Stormwoter Drainage Line

_ SSL__ _ Underground Sanitory Sewer Line

- PML _ - Underground Potable Water line
Martin Marietta Energy Systems, Inc. Environmental Management Deportment FIGURE 2-4

Horizontal Extent of Benzene Contamination in Groundwater At The Rust Garage Facility 


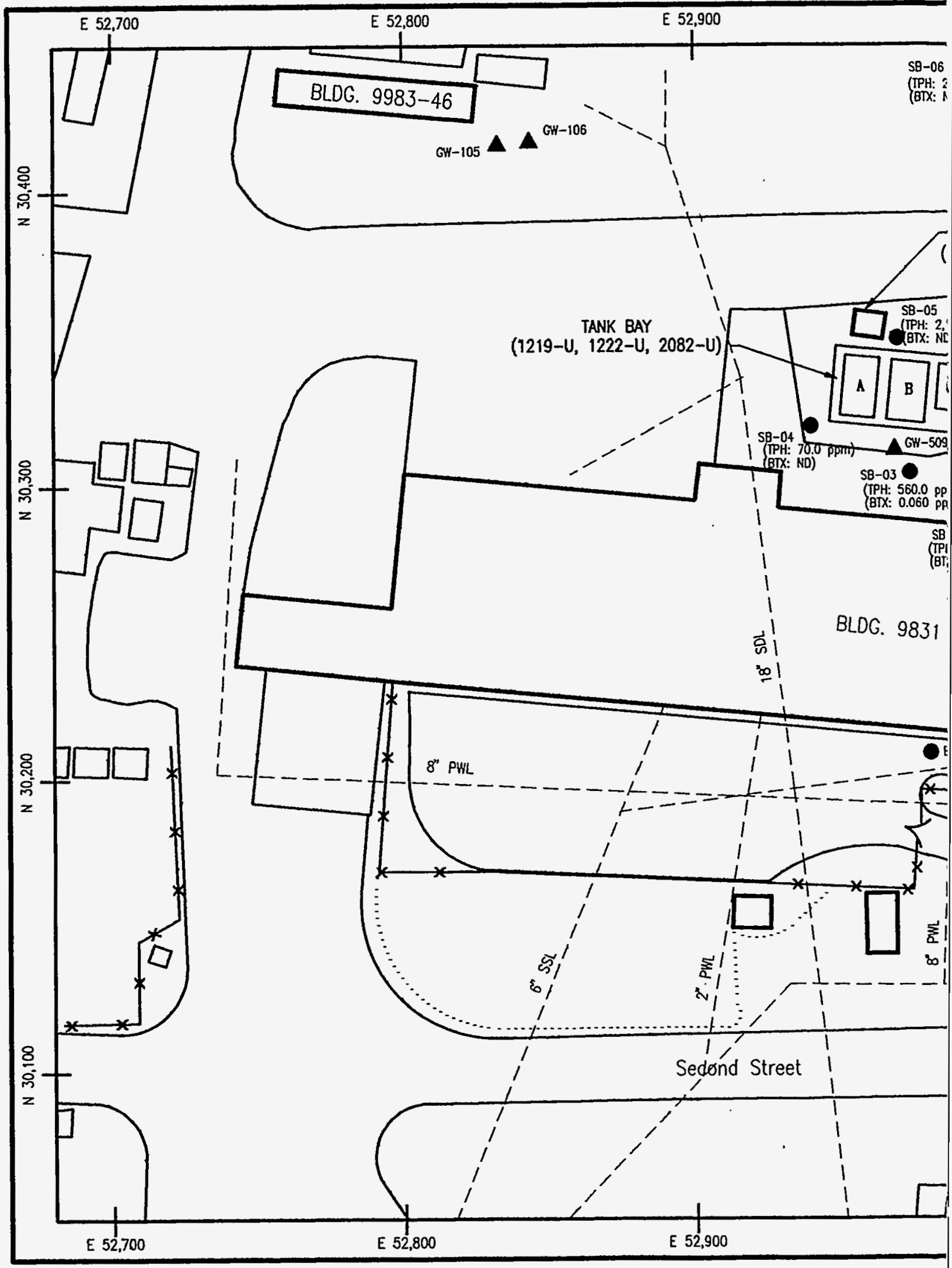

All location informotion presented in this figure is based upon MMES engineering drowings, results of previous MMES investigations, and/or field determinations of feoture and sampling locations. No representotion or worronty, expressed or implied, is made os to the occuracy of the informotion or stotements presented in this figure.

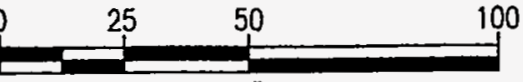

SCALE: $1^{\prime \prime}=50^{\prime}$

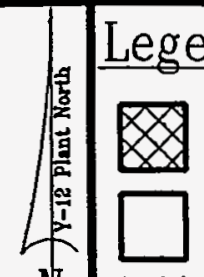

nd

Groundwoter Contamination: $>1.0 \mathrm{ppm} \mathrm{TPH}$

Groundwater Contamination: $>0.1 \mathrm{ppm}$ TPH 


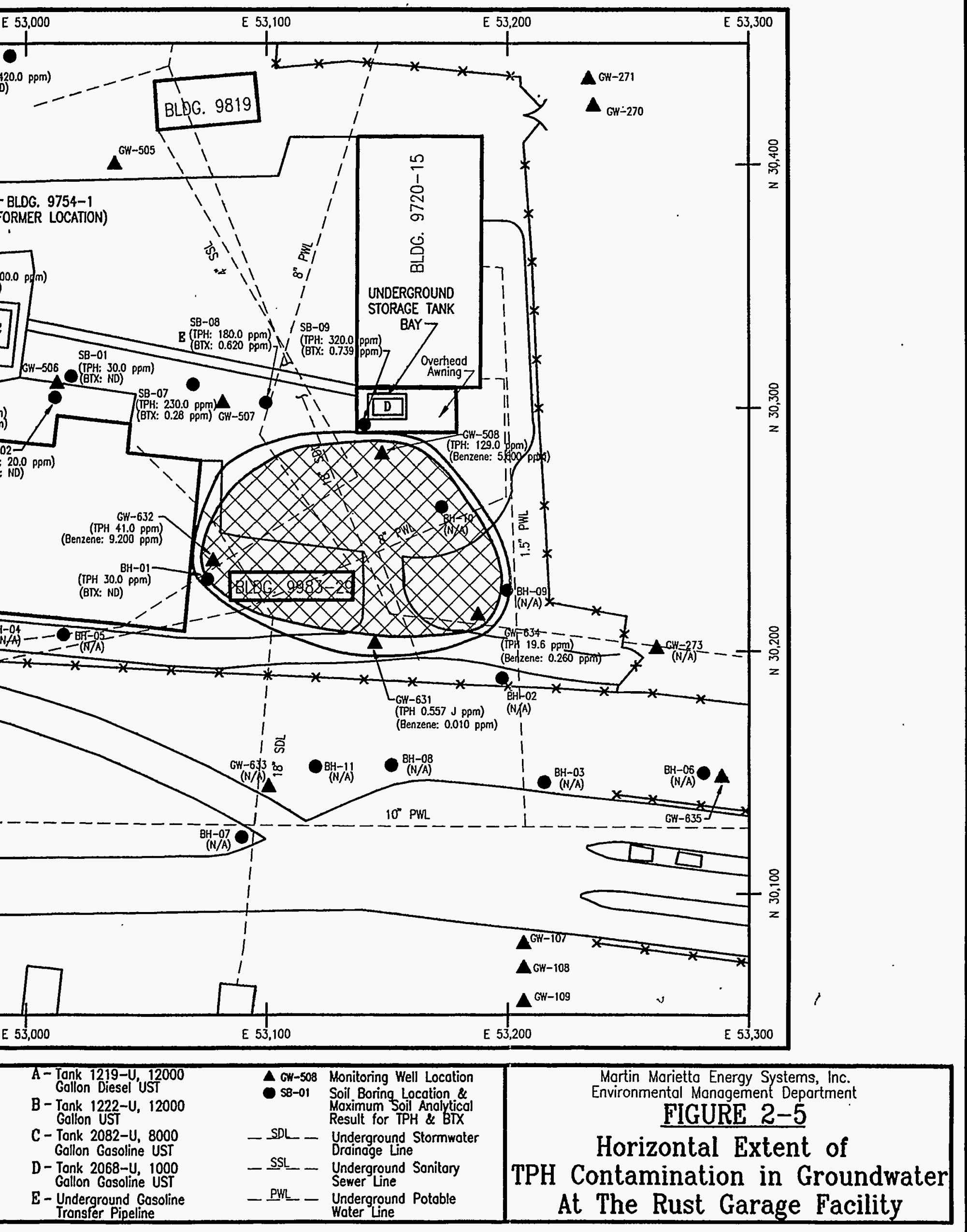




\subsection{VAPOR MONITORING}

\subsection{MONITORING METHOD AND LOCATIONS}

Vapor monitoring as part of the comprehensive monitoring program was conducted on April 28, 1994. Access points for three storm sewers and one sanitary sewer were monitored. The locations of sampling points are illustrated on Figure 3-1. Locations F-305C and F-3105 are the only accessible substructures within the delineated groundwater contamination plume.

At each location, organic vapors were monitored using direct-reading instruments. Organic vapors were monitored using a Thermo Environmental ${ }^{\mathrm{TM}}$ organic vapor meter. Oxygen, lower explosive limit (LEL), hydrogen sulfide, and carbon monoxide were monitored using a Gastech Fourrunner ${ }^{\mathrm{TM}}$.

\subsection{VAPOR MONITORING RESULTS}

The results of vapor monitoring at the Rust Garage Facility are presented in Table 3-1. Measured oxygen percentages are within the range of normal air concentrations. LEL readings of $0 \%$ at all the monitored sites indicate that an explosion hazard does not exist within the monitored utilities. Monitoring results for both hydrogen sulfide and carbon monoxide reveal levels well below the time weighted average (TWA) exposure limits of $10 \mathrm{ppm}$ and $35 \mathrm{ppm}$ (respectively) reported by the American Conference of Governmental Industrial Hygienists (1993-1994). With the exception of monitoring results for location F-3105, organic vapor readings are equal to background readings. The organic vapor reading of $1.2 \mathrm{ppm}$ at location F-3105 may be due to the presence of petroleum contamination or other organic compounds (naturally occurring or manmade) at the site. The non-discriminatory nature of the organic vapor meter used in the monitoring does not allow specific identification of the source. 


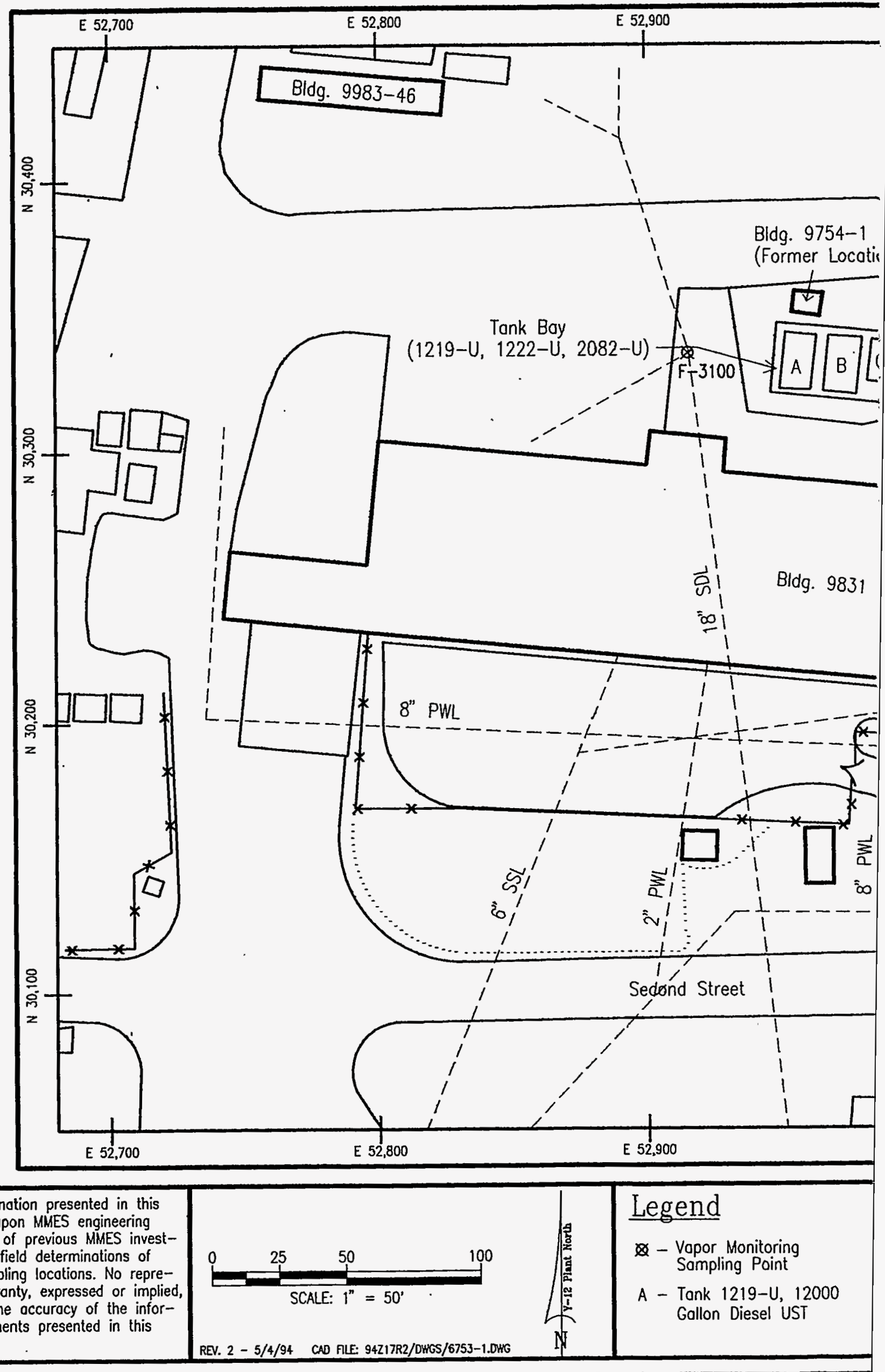

All location information presented in this figure is bosed upon MMES engineering drawings, results of previous MMES investigations, and/or field determinations of feature and sampling locations. No representation or warranty, expressed or implied, is made os to the accuracy of the information or stotements presented in this figure. 


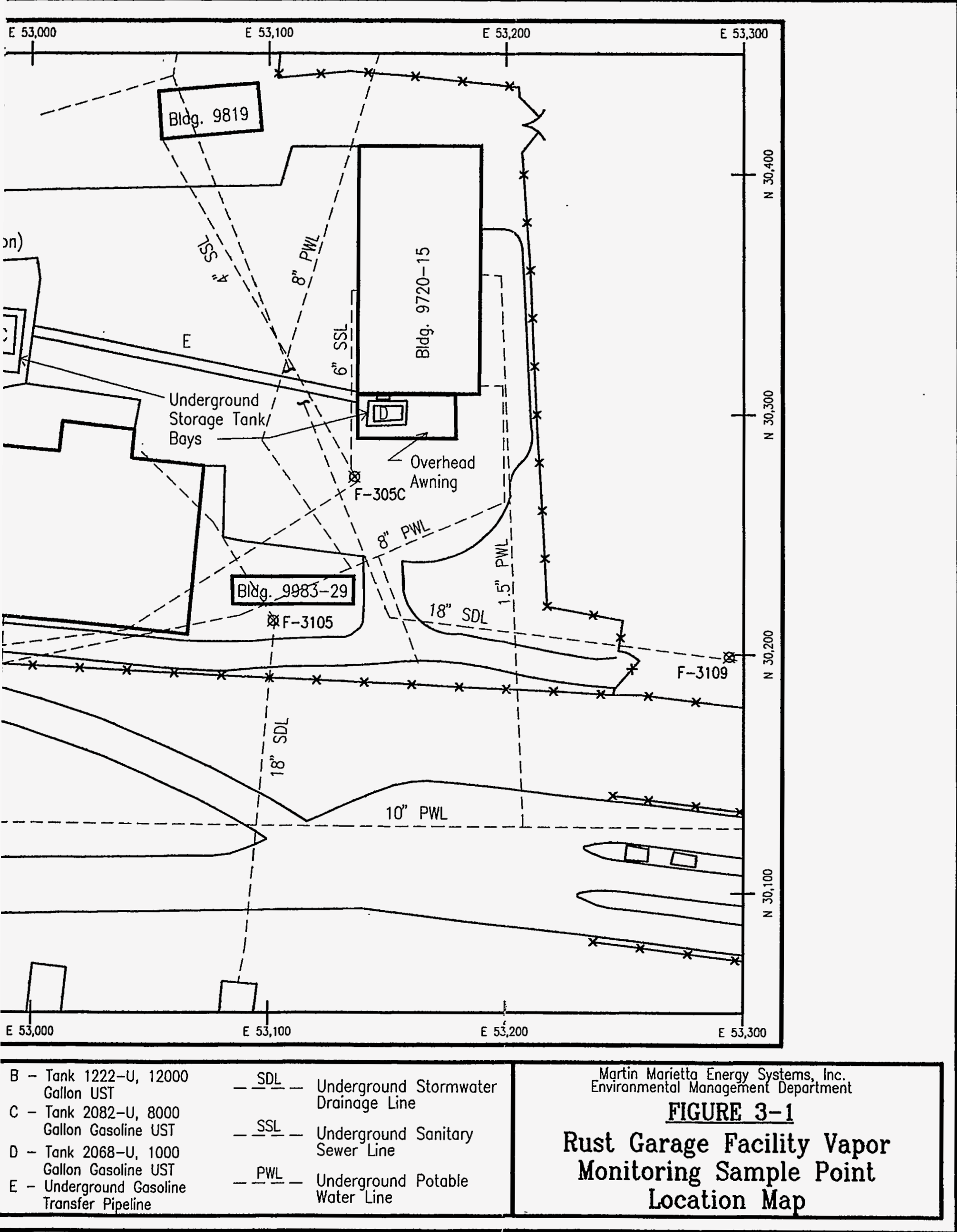


Table 3-1. Vapor Monitoring Results for the Rust Garage Facility

\begin{tabular}{lcccccc}
\hline $\begin{array}{c}\text { Sampling } \\
\text { Location }\end{array}$ & $\mathbf{O}_{\mathbf{2}}(\boldsymbol{\%})$ & LEL (\%) & $\begin{array}{c}\mathbf{H}_{2} \mathbf{S} \\
(\mathbf{p p m})\end{array}$ & $\begin{array}{c}\text { Co } \\
\text { (ppm) }\end{array}$ & $\begin{array}{c}\text { Organic } \\
\text { Vapors } \\
\text { (ppm) }\end{array}$ & $\begin{array}{c}\text { Background } \\
\text { Organic } \\
\text { Vapors (ppm) }\end{array}$ \\
\hline F-3100 & 21.0 & 0 & 0.0 & 6 & $0.0-0.4$ & $0.0-0.4$ \\
F-305C & 21.0 & 0 & 0.0 & 8 & $0.0-0.4$ & $0.0-0.4$ \\
F-3105 & 21.0 & 0 & 0.5 & 7 & 1.2 & 0.0 \\
F-3109 & 20.9 & 0 & 0.0 & 2 & 0.2 & $0.0-0.2$ \\
\hline
\end{tabular}




\section{REFERENCES}

Harless, J., personal communication to R. Spence, March 7, 1994.

Energy Systems (Martin Marietta Energy Systems) 1992. Corrective Action Plan for Underground Storage Tanks 1219:U, 1222-U, 2082-U, and 2068-U at the Rust Garage Facility, Buildings 9720-15 and 9754-1, Appendix E, Martin Marietta Energy Systems, Inc. Y/SUB/9299928C/1.

Energy Systems 1994. Calendar Year 1993 Groundwater Quality Report for the Upper East Fork Poplar Creek Hydrologic Regime, Y-12 Plant, Oak Ridge, Tennessee: 1993 Groundwater Quality Data and Calculated Rate of Contaminant Migration.

TDEC (Tennessee Department of Conservation) 1994. The TDEC UST Reference Handbook, 2nd ed. 


\section{DISTRIBUTION}

Health, Safety, Environment, and Accountability Organization

D.E. Bohrman (2)

L.L. Cunningham/E.M. Ingram

L.W. McMahon

File - EMD - RC

\section{Environmental Compliance}

Organization

\section{S.H. Welch}

Tennessee Department of Environment and Conservation

C. Head

E.C. Leming/J.D. Harless

\section{U.S. Department of Energy}

E.M. Atkins

R.J. Spence/W.G. McMillian

S.R. Lankford

\section{A.K. Lee/DOE-OSTI (2) \\ Y-12 Central Files}


APPENDIX A

LABORATORY ANALYTICAL RESULTS FOR COMPREHENSIVE MONITORING 
UNCIASSIFIED

\section{FACILITY ID 0-010117 BUILDINGS 9720-15/9754-1}

OFFICIAL REPORT

$35 / 26 / 94 \quad 13: 13: 54$

¿UBMITTER

Johrman, Donald Edwa

IATE SAMPLED: 04/05/94 12:31:00

JATE RECEIVED: 04/05/94

IAMPLER: 029776
Y-12 ANALYTICAL SERVICES ORGANIZATION
PAGE 1 OF 1

:OMMENTS: GW-508 DON BOHRMAN NEEDS RESULTS AS SOON AS POSSIBLE.

\begin{tabular}{|c|c|c|c|c|}
\hline CUSTOMER ID & REQ NO & SAMPLE NO & MTC & STATUS \\
\hline GH-508 B & & $\overline{E 940940016}$ & 8601 & APPROVED \\
\hline $\begin{array}{l}\text { LOCATION: RUST } \\
\text { PROJECT CODE: }\end{array}$ & AGE & & $\begin{array}{l}\text { CHARE } \\
\text { CASE: }\end{array}$ & $\begin{array}{l}\text { : S2205F28 } \\
1057\end{array}$ \\
\hline
\end{tabular}

FINAL APPROVAL:

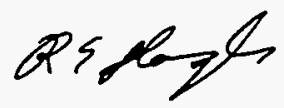

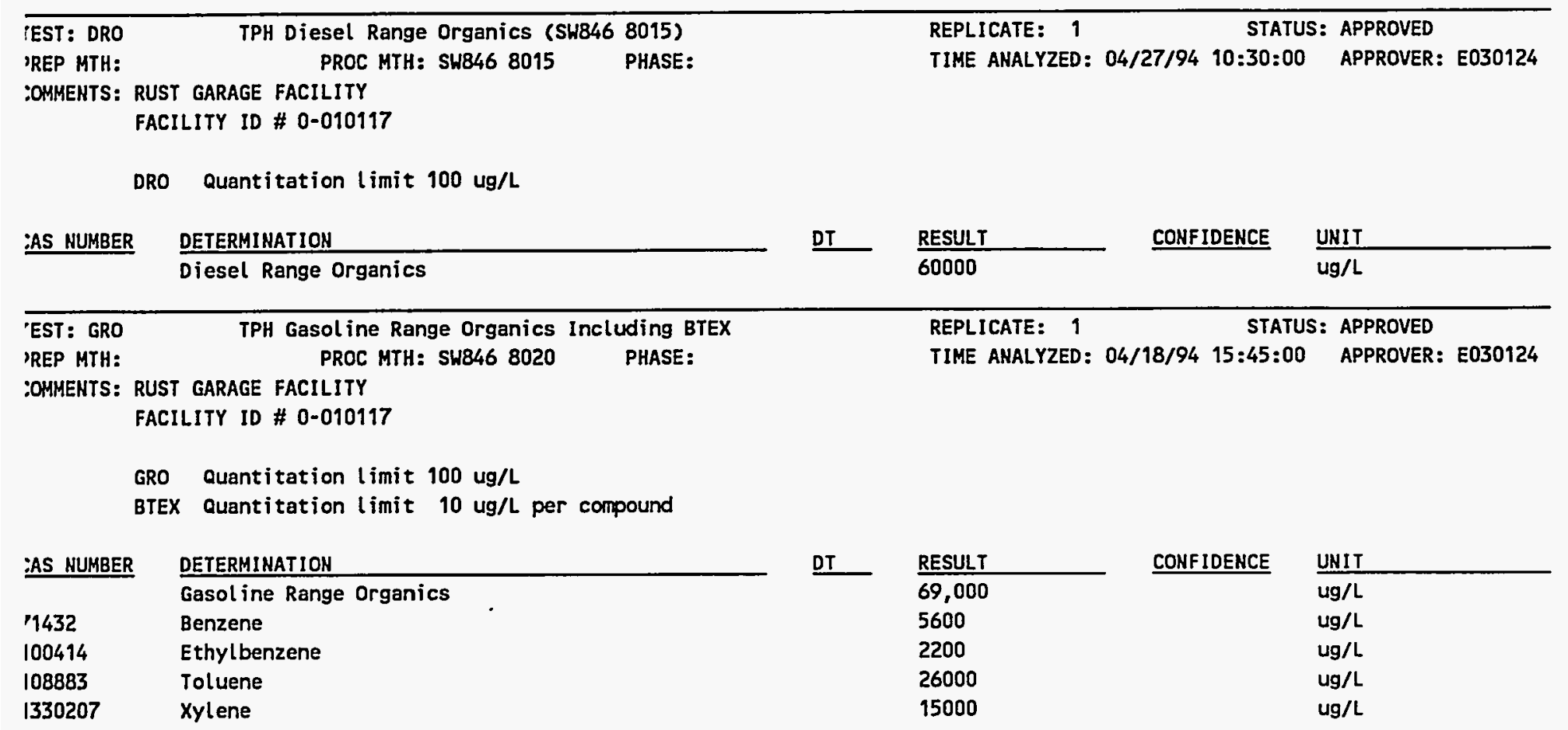

UNCLASSIFIED 


\section{FACILITY ID 0-010117 BUILDINGS 9720-15/9754-1}

OFFICIAL REPORT

;/26/94 13:13:09

\section{JBMITTER}

Shrman, Donald Edwa

ITE SAMPLED: 04/05/94

ITE RECEIVED: 04/05/94

LMPLER: 029776
Y-12 ANALYTICAL SERVICES ORGANIZATION
PAGE 1 OF 1

MMENTS: GW-632 DON BOHRMAN NEEDS RESULTS AS SOON AS POSSIBLE.

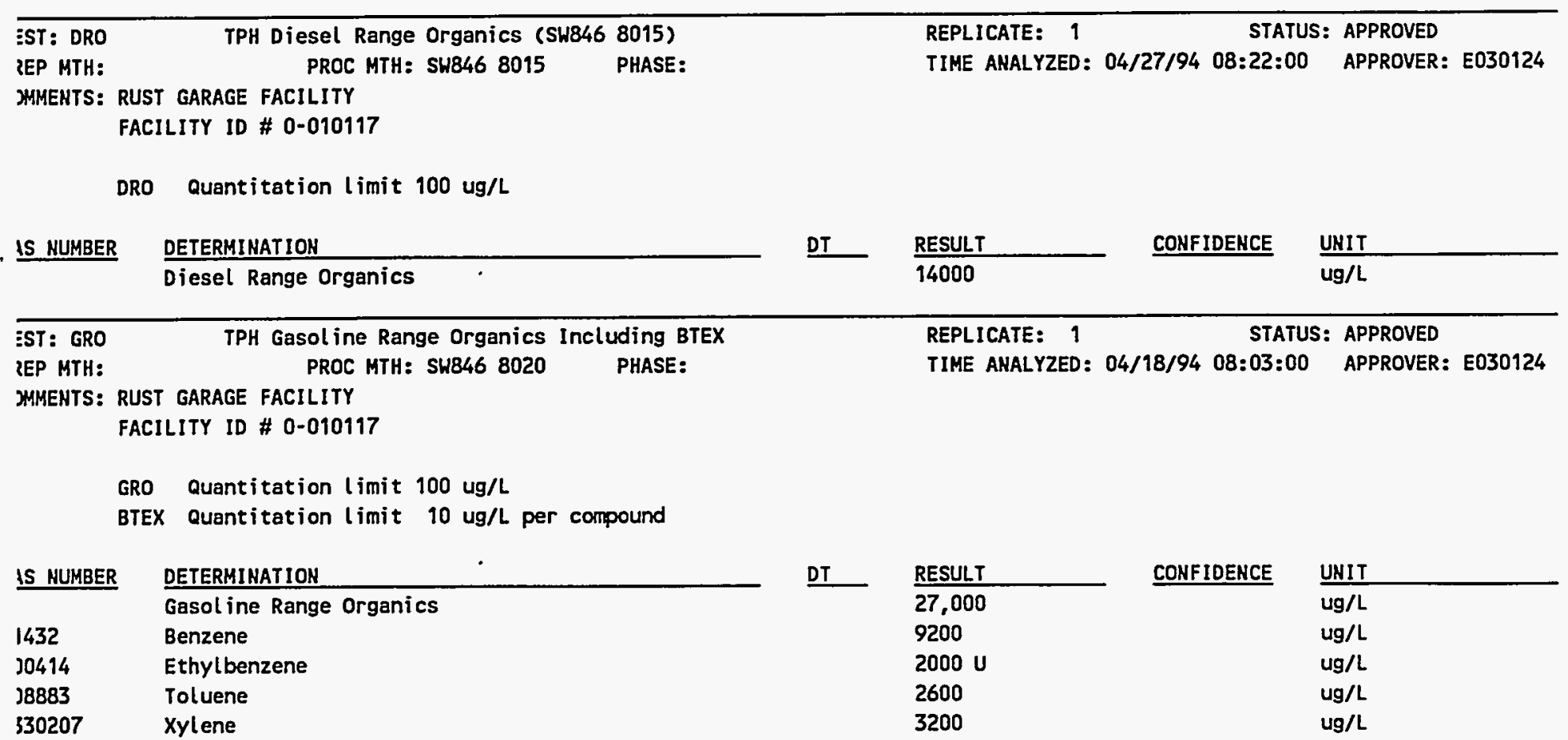

\section{ADDRESS}

Building 9115 MS 8219

DATE MEEDED: 04/08/94

DATE COMPLETED: 04/28/94

SAMPLE DESCRIPTION: GRAB
CUSTOMER ID R REQ NO SAMPLE NO

GH-632 B E940940014

LOCATION: RUST GARAGE GH-632

PROJECT COOE:

FINAL APPROVAL:
MTC STATUS 8601 APPROVED CHARGE \#: S2205F28 CASE: 001057 Toluen 3200

ug/L 
$15 / 26 / 94 \quad 13: 13: 39$

UUBMITTER

iohrman, Donald Edwa

ATE SAMPLED: 04/05/94 11:52:00

ATE RECEIVED: 04/05/94

AMPLER: 029776
UNCLASSIFIED

OFFICIAL REPORT
Y-12 ANALYTICAL SERVICES ORGANIZATION

\section{FACILITY ID 0-010117 BUILDINGS 9720-15/9754-1}

OMMENTS: GW-634 DON BOHRMAN NEEDS RESULTS AS SOON AS POSSIBLE.

\begin{tabular}{|c|c|c|c|c|}
\hline CUSTOMER ID & REO NO & SAMPLE NO & MTC & STATUS \\
\hline GW-634 B & & E940940015 & 8601 & APPROVED \\
\hline $\begin{array}{l}\text { LOCATION: RUS } \\
\text { PROJECT COOE: }\end{array}$ & RAGE & & $\begin{array}{l}\text { CHARE } \\
\text { CASE: }\end{array}$ & $\begin{array}{l}=52205 F 28 \\
1057\end{array}$ \\
\hline
\end{tabular}

FINAL APPROVAL:

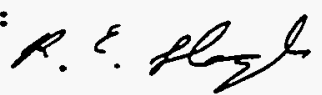

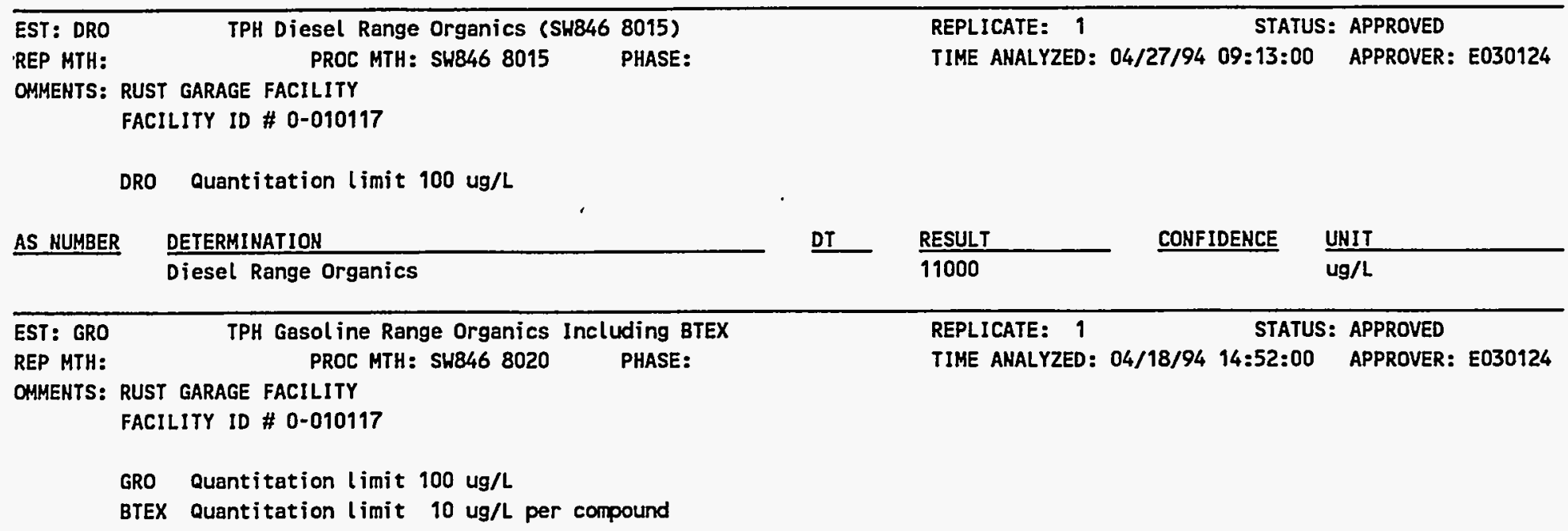

\begin{tabular}{|c|c|c|c|c|c|}
\hline AS NUMBER & DETERMINATION & DT & RESULT & CONFIDEHCE & UNIT \\
\hline & Gasol ine Range Organics & & 8600 & & $\overline{u g / L}$ \\
\hline 1432 & Benzene & & 260 & & $\mathrm{ug} / \mathrm{L}$ \\
\hline 00414 & Ethylbenzene & & 500 & & $\mathrm{ug} / \mathrm{L}$ \\
\hline 08883 & Toluene & & 340 & & $\mathrm{ug} / \mathrm{L}$ \\
\hline 330207 & Xylene & & 1900 & & ug/L \\
\hline
\end{tabular}

UNCLASSIFIED 
OFFICIAL REPORT

$; / 26 / 94 \quad 13: 14: 02$

\section{JBMITTER}

Jhrman, Donald Edwa

ITE SAMPLED: 04/05/94 08:00:00

ITE RECEIVED: 04/05/94

WMPLER: 29776
Y-12 ANALYTICAL SERVICES ORGANIZATION

PAGE 1 OF 1

MMMENTS: TRIP BLANK FOR GH-631,GH-632,GH-634,GH-508. DON BOHRMAN NEEDS RESULTS ASAP.

\section{ADDRESS}

Building $9115 \quad$ MS 8219

DATE NEEDED: 04/08/94

DATE COMPLETED: 04/20/94

SAMPLE DESCRIPTION: TRIP BLANK

$\frac{\text { CUSTOMER ID }}{\text { TRIP BLANK }}$ REQ NO $\frac{\text { SAMPLE NO }}{\text { E940940018 }}$

LOCATION: BLDG. 9207

PROJECT CODE:
MTC STATUS 8601 APPROVED CHARGE \#: S2211601 CASE: SQTOO1

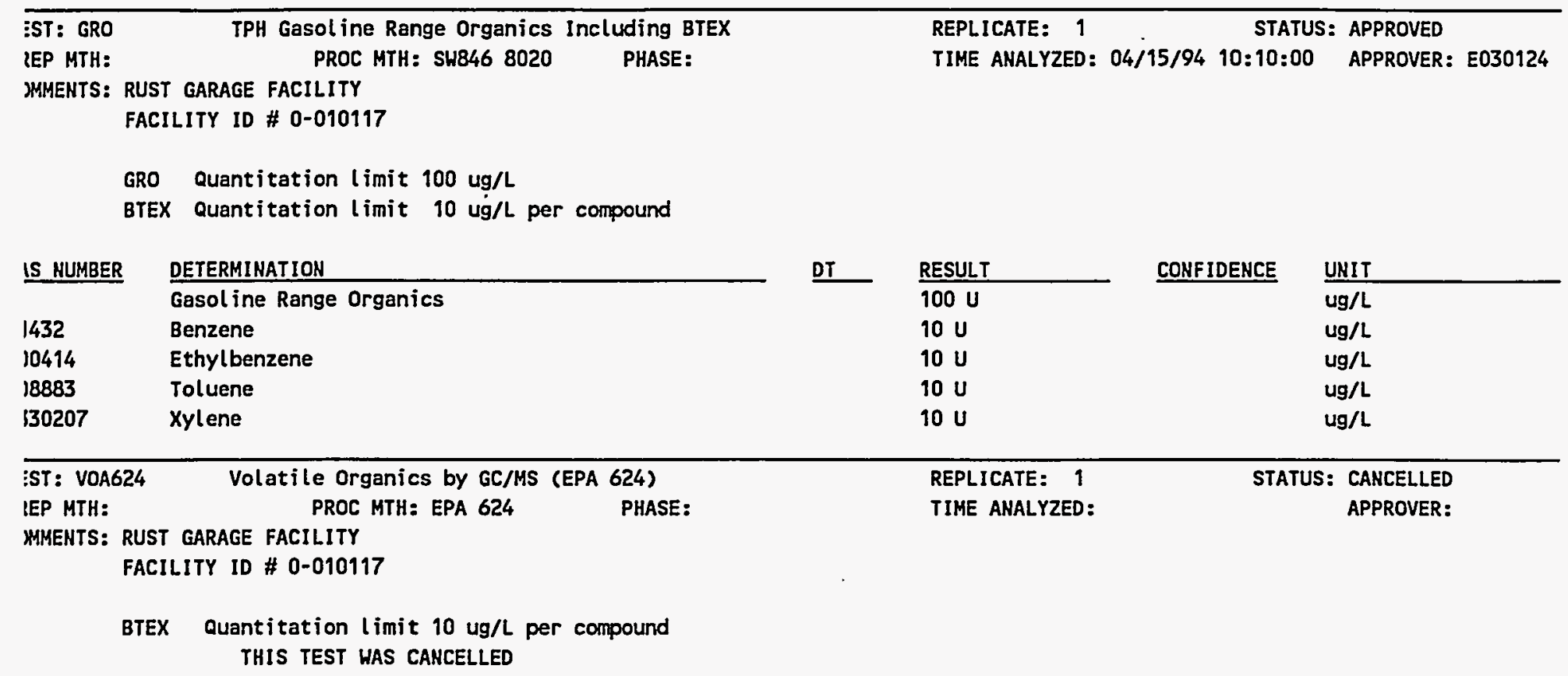


FACILITY ID 0-010117

BUILDINGS 9720-15/9754-1

PJN-1057 DOE Y-12 PLANT CHAIN OF CUSTODY FORM S.2205F28 No 17841

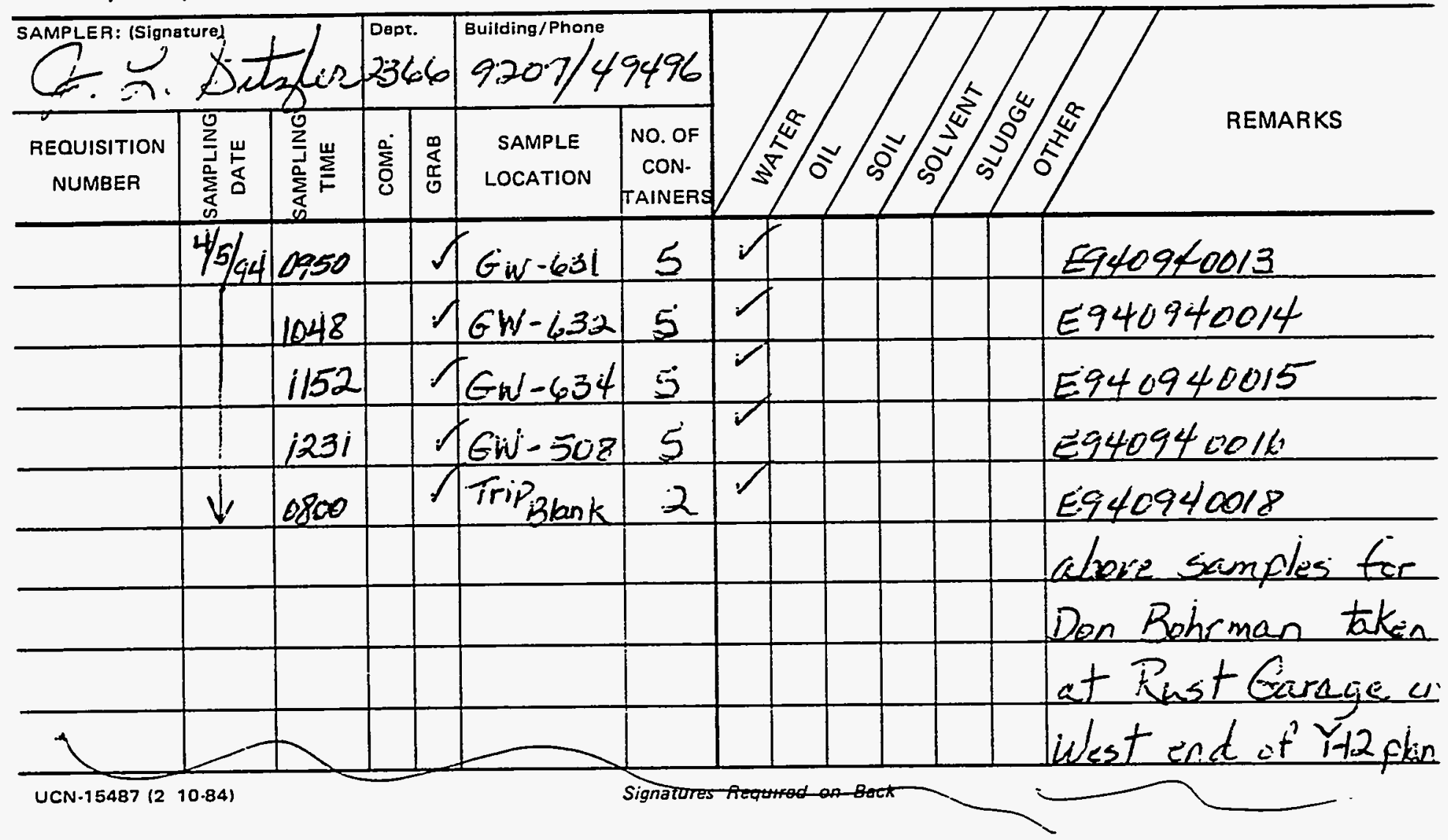




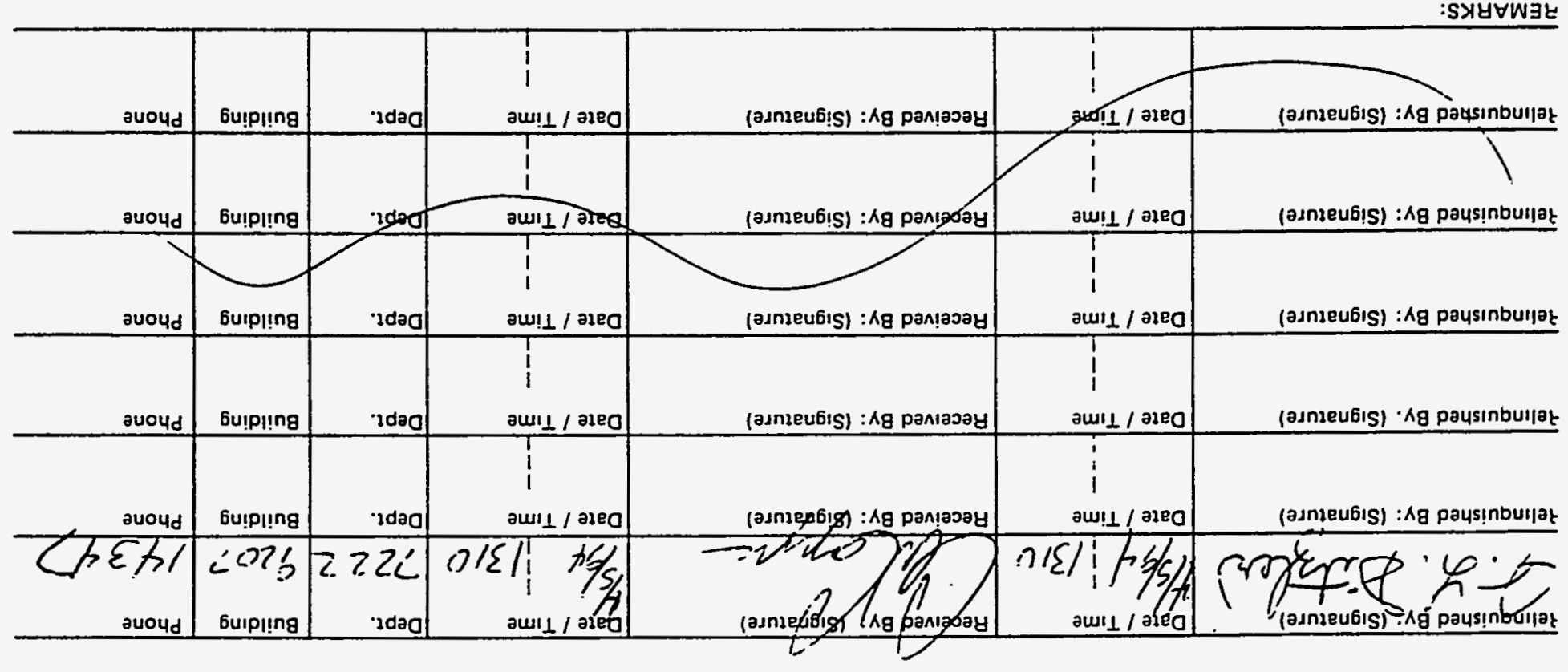

